Original Research Paper

\title{
Risk Assessment of Heavy Metals in Fish in Saudi Arabia
}

\author{
Othman M. Hakami \\ Department of Chemistry, Faculty of Sciences, Jazan University, Jazan, Saudi Arabia
}

Article history

Received: 24-08-2016

Revised: 22-08-2016

Accepted: 02-12-2016

Email: omhakami@jazanu.edu.sa

\begin{abstract}
Heavy metals such as arsenic, cadmium, mercury and lead constitute a serious threat to human health. Generally, regular consumption of fish is recommended because it is a good source of omega-3 fatty acids, which have been associated with health benefits. However, flesh of some fish species contains heavy metals in high concentration, which may pose health risk for individuals that consume them in significant quantities. Therefore, over the last few years, evaluation of heavy metals in fish has become a matter of great global concern and especially in Kingdom of Saudi Arabia.The aim of the present work was toassess the concentration of the most toxic heavy metals present in fish caught along the eastern and western coasts of Saudi Arabia, which was achieved through several studies. Results yielded by analyzing 73 fish species and 1,027 edible fish part samples from 12 sampling sitesrevealed considerable variation in metal concentrations across the sampling locations and fish species. Amounts of some of heavy metals were below the maximum allowed limit. Moreover, high hazard index $(\mathrm{HI}>10)$ was obtained for the consumption of some fish species caught at specific sites, which indicates a high probability of consuming populations experiencing adverse health effects.
\end{abstract}

Keywords: Health Risk Assessment, Fish, Contamination, Heavy Metals, Red Sea, Arabian Gulf

\section{Introduction}

Fish seems to be the perfect healthy food, since many species are rich in the polyunsaturated fatty acid Omega3 , which is widely acclaimed as beneficial the human health and optimal heart functioning. However, eating too much fish can cause a buildup of heavy metals, such as arsenic $(A s)$, cadmium $(C d)$, lead $(\mathrm{Pb})$, mercury $(\mathrm{Hg})$, chromium $(\mathrm{Cr})$ and nickel $(\mathrm{Ni})$. In fact, heavy metals accumulate in different vital parts of smaller fish, including heart, liver and tissues, by different natural or accidental causes (Paulino et al., 2014; Jayaprakash et al., 2015; Dural et al., 2006; Fernandes et al., 2007). As the contaminated small fish species are food source for bigger fish, which are eaten by even bigger fish and so on, this results in bio-accumulation (Malik et al., 2010; Al-Kahtani, 2009). Consequently, these heavy metal elements bio-accumulate at high doses in bigger species, like shark or swordfish (Xiphias gladius (Linnaeus, 1758)). Commonly consumed fish, e.g., grouper and emperor fish, can contain significant concentrations of these toxic elements as well. For most people this is not a problem, as the benefits derived from fish consumption far outweigh any adverse effects. However, consumption of contaminated fish during pregnancy could harm vital organs and processes in a developing fetus. Exposure to heavy metals might be linked to Attention Deficit Hyperactivity Disorder (ADHD) issues in young population, i.e., infants and children, according to one study published in the Journal Archives of Pediatrics and Adolescent Medicine (Stratakis et al., 2016). To avoid these adverse effects, the Food and Drug Administration (FDA) suggested that pregnant and breastfeeding women limit consumption of fish species that contain the highest levels of mercury, such as swordfish (Xiphias gladius), shark, tilefish (Lopholatilus chamaeleonticeps) and kingfish (Scomberomorus cavalla) (Burger, 2009; Lando and Lo, 2014). FDA further recommends eating Albacore tuna (Thunnus alalunga)no more than twice a week. This prompts the question: "Where do all these heavy metals come from?" Heavy metals are natural elements found throughout the environment. Some scientists are of view that they form naturally in the Earth's core and emerge to the surface through 
hydrothermal vents (Minic et al., 2006) or volcanic eruptions (Calabrese et al., 2015). While this is likely the case, human activity results insubstantial quantities of heavy metal waste from power plants and manufacturing industries, such as mining activities, oil refinery or urban wastewater treatment plants. While some safeguards are in place, some facilities discharge their waste into the environment resources (sea, soils, river, etc.) without adequate preprocessing. Once these toxins reach seas and oceans, they enter fish metabolism and build up in their tissues. Fish body mechanism turn the most known toxic element mercury into a high toxic form, methylmercury. According to the United States Environmental Protection Agency (US EPA) (USEPA, 2005), "Nearly all fish and shellfish contain traces of methylmercury" (Mahaffey et al., 1999). Other underwater ecosystems like coral are also affected, confirming that heavy metals pose a serious environmental threat. In fact, Kingdom of Saudi Arabia has a unique geographical location characterized by $2,640 \mathrm{~km}$ of coastline belt along the Red Sea in the west and the Arabian Gulf in the east. According to FAO Fisheries and Aquaculture Department statistics, the Kingdom produced about 23,880 tons of marine products in 2014 (FAO, 2016). Thus, the country is an important source of a wide range of fish suitable for commercial exploitation and local population consumption. Recent studies on Saudi population consumption patterns (Burger et al., 2015; Selvanathan et al., 2015; Burger et al., 2014a) show that marine products, fish in particular, are widely consumed. Hence, to avoid the adverse health effects associated with heavy metal contamination, the $G C C$ Standardization Organization (GSO) (GSO-GCC, 2016) has established technical standards and regulations for maximum levels of contaminants and food toxins (Dreyer et al., 2007; Al-Rubaie et al., 2014). To evaluate the health risk the Saudi people are exposed to through consumption of marine products, many researchers working in academic institutions throughout the Kingdom have attempted to assess heavy metal levels in fish (Al-Misned and Mortuza, 2015; Idris et al., 2015; Kamal et al., 2015; Burger et al., 2014b; Mahboob et al., 2014; Said et al., 2014). Different fish species and sampling locations were studied (Al-Misned and Mortuza, 2015; Idris et al., 2015; Kamal et al., 2015; Burger et al., 2014b; Mahboob et al., 2014; Said et al., 2014). Burger et al. (2014b) examined traces of heavy metals in 13 different fish species collected from three fishing sites and a local fish market in Jeddah, Saudi Arabia. Their findings revealed high levels of arsenic in Epinephelus tauvina, as well as Aphareus rutilans, Carangoides bajad (C. bajad) and Plectropomus areolatus. Mercury and methylmercury traces were also detected in high levels in the Jeddah coastal area in four fish species (Cephalopholis argus, C. bajad, Variola louti and Lethrinus lentjan). Thus, the authors concluded that mercury poses the greatest risk associated with fish consumption, while arsenic is also of concern (Burger et al., 2014b). Many researchers have also performed comparisons with international permissible limits and have estimated health risks (Al-Misned and Mortuza, 2015; Idris et al., 2015; Kamal et al., 2015; Burger et al., 2014; Mahboob et al., 2014; Said et al., 2014). However, to the best of our knowledge, formal risk assessments performed by using site-specific experimental data, along with site-specific information on consumption patterns using exposure scenarios is presently lacking. In addition, very few authors have attempted to evaluate the health risk related to heavy metals when found in trace amounts in fish consumed by Saudi population. In their work, Idris et al. (2015) calculated human risk indices as Average Daily Dose $(A D D)$ and Hazard Index (HI) using the US EPA classical calculation method with a fixed Ingestion Ratio (IR) and an average body weight equal to $70 \mathrm{~kg}$ for normal adults. This approach does not take into account the real consumption patterns of Saudi people and, as it is age independent, it does not specifically address vulnerable population groups. In this study, these shortcomings are overcome by conducting a complete survey pertaining to all heavy metal elements (As, Cd, $\mathrm{Pb}, \mathrm{Hg}, \mathrm{Cr}$, $\mathrm{Ni}$ and $\mathrm{MeHg}$ ) currently recognized as potentially highly toxic, which are present in fish species commercially fished from the eastern and western Saudi coastal belt. All the reported data are discussed and subjected to the standard Risk Assessment (RA) approach, which comprises of four standard steps, i.e., (1) Hazard Identification; (2) Hazard Characterization; (3) Exposure Assessment and (4) Risk Characterization.

\section{Survey on Heavy Metal Contamination of Fish}

Since the effects of industrial human activities on the environment are becoming increasingly pronounced, national (SASO, SFDA), regional (GSO) and international governmental agencies and organizations (WHO, USEPA, FAO, JECFA) are dedicating substantial efforts to the protection of human health and environment. This is typically achieved by establishing strict policies and standards in order to limit and reduce the environmental contaminants in the human food chain. Four heavy metals-arsenic $(\mathrm{As})$, cadmium $(\mathrm{Cd})$, lead $(\mathrm{Pb})$ and mercury $(\mathrm{Hg})$-are classified by $W H O$ in the top 10 chemicals of "major 
public health concern" (WHO, 2016). Table 1 presents the maximum permissible limits and Provisional Tolerable Weekly Intake (PTWI) of arsenic, cadmium, lead, mercury, methylmercury, chromium and nickel based on different international and national standards. These limits and specifications can vary depending on fish species and edible parts, as noted in Table 1 .

In the present study, data pertaining to fish heavy metal contamination were collected from 10 peerreviewed papers related to the Saudi Arabian case. Table 2 provides a summary of the findings reported in these scientific resources for the western (Red Sea fisheries) and eastern (Arabian Gulf fisheries) Saudi Arabian coastal belts.

\section{Eastern and Western Saudi Arabian Coasts}

Saudi Arabia is bordered by the Red Sea and the Arabian Gulf. The surface area of the Red Sea is about $438,000 \mathrm{~km}^{2}$; it is $2,250 \mathrm{~km}$ long and measures $355 \mathrm{~km}$ at its widest point. Several industrial activities, such as desalination plants, chemical facilities, refineries, etc., are located in the coastal areas of the Red Sea and the ArabianGulf. These industries are considered as the most important threats for the quality of the environment in this region, Saudi Arabia in particular (Al-Balwai et al., 2013). Therefore, there is an increasing concern about the quality of seafood and especially fish, caught in these waters. One of the major threats human health stems from heavy metals due to their ubiquitous presence as well as potential to enter aquatic organisms, resulting in bio-accumulation and bio-magnification in the food chain (Dhanakumar et al., 2015). Many research studies have been conducted to assess the concentrations of heavy metals in several fish species (Al-Misned and Mortuza, 2015; Idris et al., 2015; Kamal et al., 2015; Burger et al., 2014b; Mahboob et al., 2014; Said et al., 2014). As a part of our investigation, 11 publications were studied in detail. The first part of the literature review highlights the concentration of some heavy metals in fish species located in the Red Sea. As shown in Fig. 1, 37 fish species were collected from three different sites across the coastal area of the Red Sea. Nearly 733 fish samples were analyzed in order to assess concentrations of arsenic, cadmium, lead, mercury, nickel and methylmercury. Table 3 shows the three fish sampling sites and their corresponding geographic locations.

Table 1. Permissible maximum limit and Provisional Tolerable Weekly (PTWI) intake for the most toxic heavy metals (As, Cd, Pb, $\mathrm{Hg}, \mathrm{MeHg}, \mathrm{Cr}, \mathrm{Ni}$ ) as reported by different standards

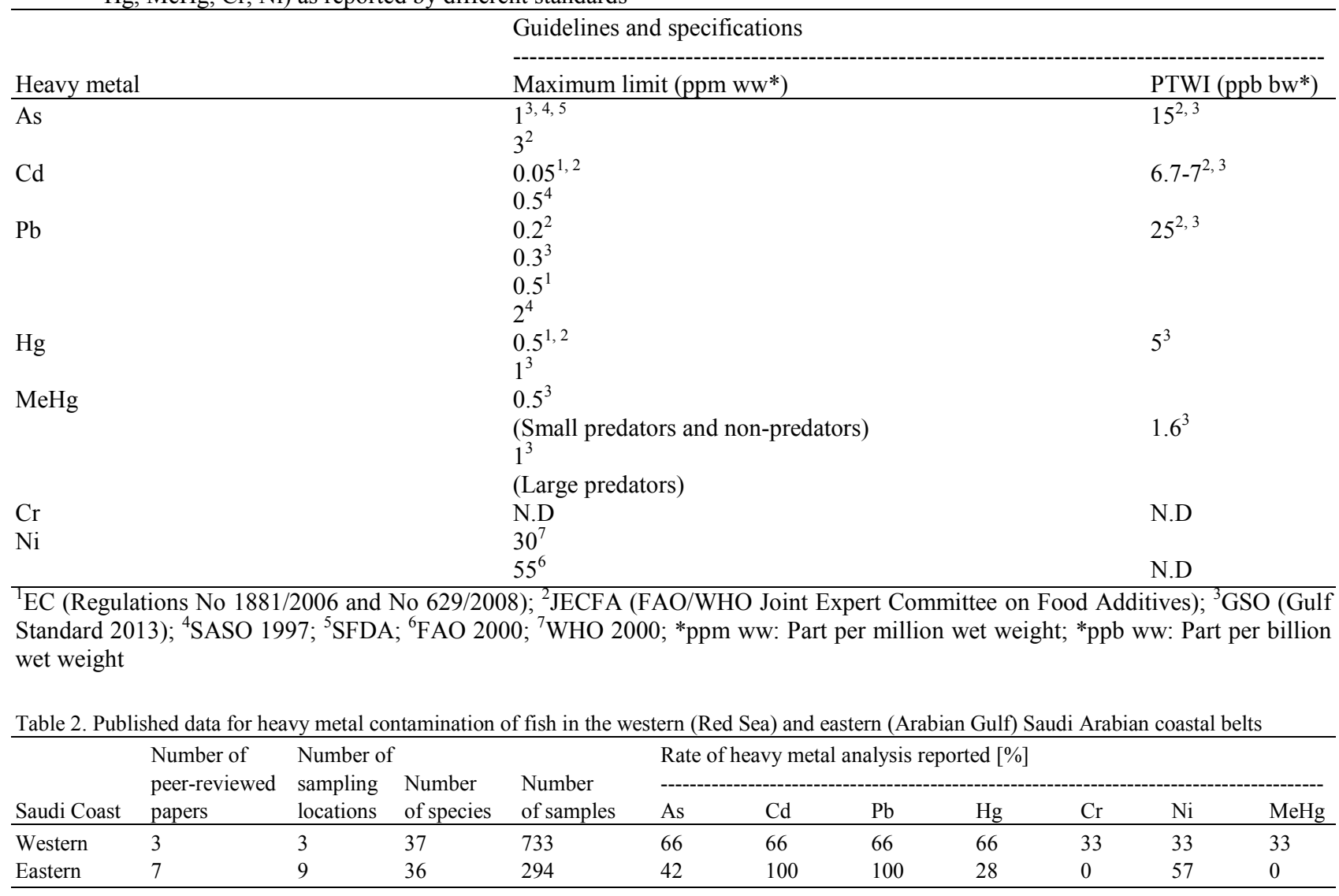


Othman M. Hakami / American Journal of Environmental Sciences 2016, 12 (6): 341.357 DOI: 10.3844/ajessp.2016.341.357

Table 3. Fish sampling sites on the western coast of KSA with the corresponding geographic locations (Longitude/Latitude)

\begin{tabular}{llll}
\hline Site number & Site name & Geographic location & References \\
\hline 1 & Djeddah, KSA & $21^{\circ} 22^{\prime} 26.7^{\prime \prime} \mathrm{N}$ & Burger et al. (2014b) \\
& & $39^{\circ} 11^{\prime} 29.6^{\prime \prime} \mathrm{E}$ & \\
& Ras-Gharib to & $28^{\circ} 21^{\prime} 09.7^{\prime \prime} \mathrm{N}$ & \\
& Ras Bonas & $33^{\circ} 04^{\prime} 47.4^{\prime \prime} \mathrm{E}$ & Hanna (1989) \\
& & $23^{\circ} 54^{\prime} 95.4^{\prime \prime} \mathrm{N}$ & Al-Ghanim et al. (2015) \\
\hline
\end{tabular}

Table 4. Fish sampling sites along the eastern coast of KSA with the corresponding geographic locations (Longitude/Latitude)

\begin{tabular}{|c|c|c|c|}
\hline Site number & Site name & Geographic location & References \\
\hline 1 & Al-Dammam, Saudi Arabia & $\begin{array}{l}26^{\circ} 29^{\prime} 39.9^{\prime \prime} \mathrm{N} \\
50^{\circ} 13^{\prime} 00.7^{\prime \prime} \mathrm{E}\end{array}$ & Al-Saleh and Shinwari (2002) \\
\hline 2 & Maniefa, Saudi Arabia & $\begin{array}{l}27^{\circ} 38^{\prime} 18.5^{\prime \prime} \mathrm{N} \\
49^{\circ} 03^{\prime} 08.3^{\prime \prime} \mathrm{E}\end{array}$ & Al-Saleh and Shinwari (2002) \\
\hline 3 & Dareen, Saudi Arabia & $\begin{array}{l}27^{\circ} 17^{\prime} 04.0^{\prime \prime} \mathrm{N} \\
49^{\circ} 37^{\prime} 36.2^{\prime \prime} \mathrm{E}\end{array}$ & Al-Saleh and Shinwari (2002) \\
\hline 4 & Coastal Areas of Bahrain, Saudi Arabia & $\begin{array}{l}26^{\circ} 12^{\prime} 28.4^{\prime \prime} \mathrm{N} \\
50^{\circ} 26^{\prime} 44.6^{\prime \prime} \mathrm{E}\end{array}$ & Madany et al. (1996) \\
\hline 5 & Qateef, Eastern province of Saudi Arabia & $\begin{array}{l}26^{\circ} 35^{\prime} 25.9^{\prime \prime} \mathrm{N} \\
50^{\circ} 01^{\prime} 47.3^{\prime \prime} \mathrm{E}\end{array}$ & Ashraf (2005) \\
\hline 6 & Bandar Abbas, Iran & $\begin{array}{l}27^{\circ} 10^{\prime} 12.1^{\prime \prime N} \\
56^{\circ} 16^{\prime} 57.6^{\prime \prime} \mathrm{E}\end{array}$ & Saei-Dehkordi and Fallah (2011) \\
\hline 7 & The northern part of Persian Gulf & N.D & Pourang et al. (2005) \\
\hline 8 & Khuzestan Province, Iran & $\begin{array}{l}30^{\circ} 25^{\prime} 27.9^{\prime \prime} \mathrm{N} \\
49^{\circ} 03^{\prime} 58.7^{\prime \prime} \mathrm{E}\end{array}$ & Hosseini et al. (2015) \\
\hline 9 & The Kharg island, Bushehr province & $\begin{array}{l}29^{\circ} 16^{\prime} 10.1 " \mathrm{~N} \\
50^{\circ} 16^{\prime} 56.5^{\prime \prime} \mathrm{E}\end{array}$ & Abadi et al. (2015) \\
\hline
\end{tabular}

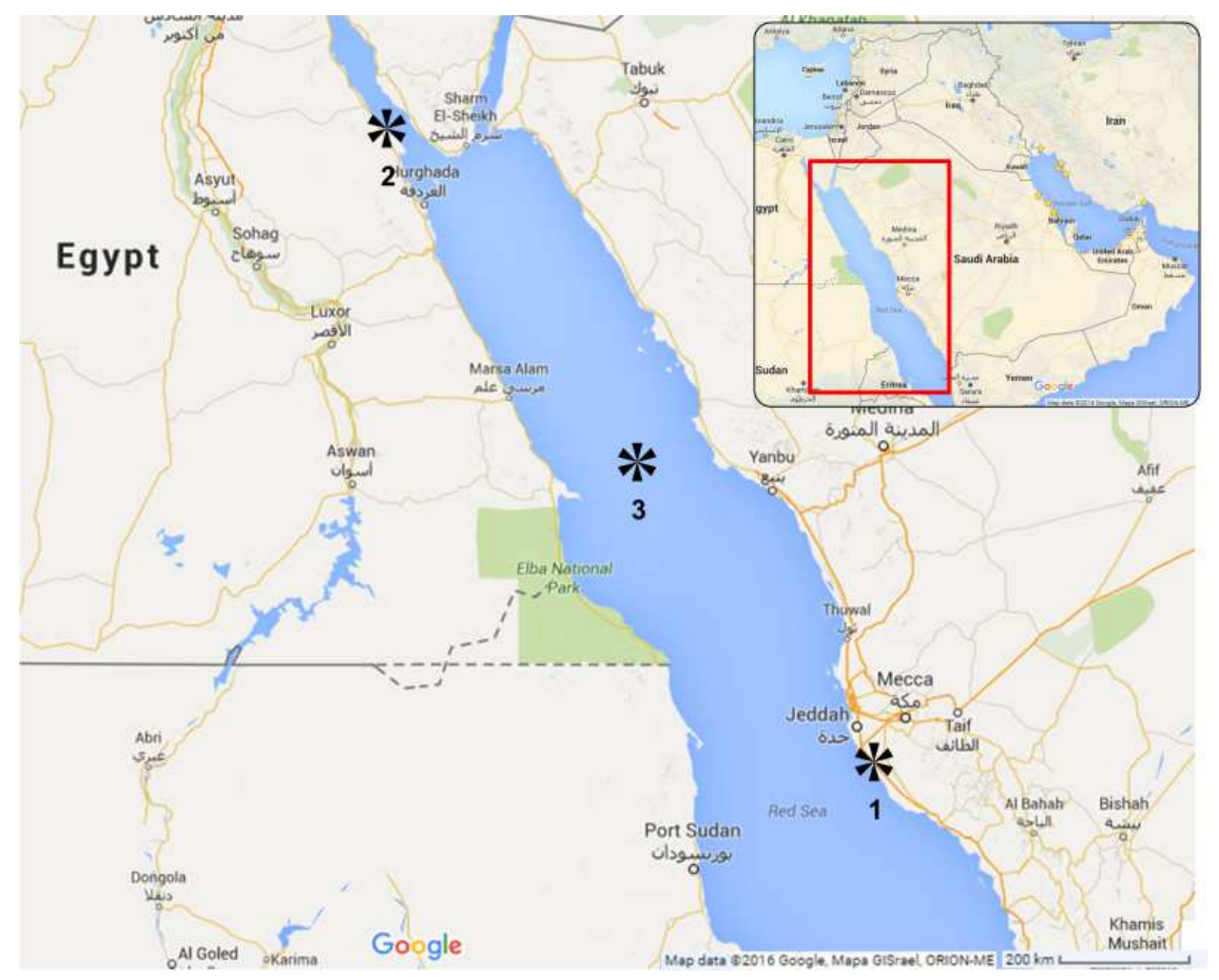

Fig. 1. Fish sampling sites for the assessment of heavy metal in fish along the western coast of Saudi Arabia 


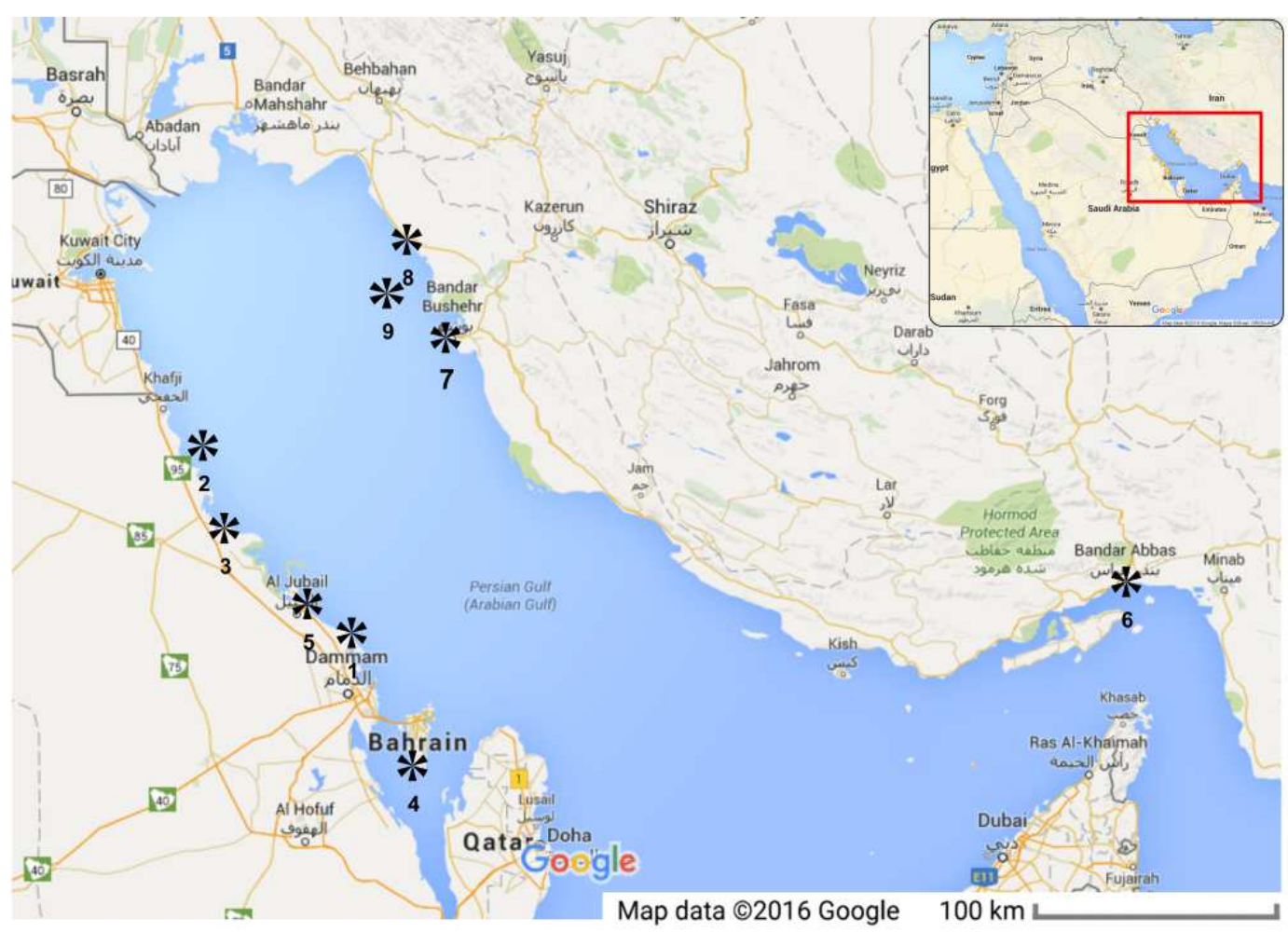

Fig. 2. Fish sampling sites for the assessment of heavy metal in fish along the eastern coast of Saudi Arabia

In the eight peer-reviewed publications included in this review that focused on the eastern Saudi Arabian coast, 36 fish species were collected from 9 different fish sampling sites, as shown in Fig. 2. Table 4 summarizes these sites with their geographic coordinates. It is evident that these sampling sites are well distributed across the Arabian Gulf, thus providing a complete survey on heavy metal concentration in fish.

In order to determine arsenic, cadmium, lead, mercury and nickel concentrations, 413 fish simples were analyzed using different experimental methods, including Polarized Zeeman Atomic Absorption Spectrophotometry (PZAAS) (Al-Saleh and Shinwari, 2002), potentiometric stripping analysis (Saei-Dehkordi and Fallah, 2011), or Inductively Coupled Plasma Mass Spectrometry (ICPMS) (Pourang et al., 2005).

\section{Heavy Metal Concentrations}

\section{Arsenic Concentration}

Much of the arsenic in fish is present in the form of organic compounds, such as arsenocholine $\left(\mathrm{C}_{5} \mathrm{H}_{14} \mathrm{AsO}^{+}\right)$, tetramethylarsonium and arsenobetaine $\left(\mathrm{C}_{5} \mathrm{H}_{11} \mathrm{AsO}_{2}\right)$ ions, rather than as inorganic arsenic. In the present study, published data on the concentrations of total arsenic are reported. The quantitative data on arsenic concentrations and speciation in fish are limited, with organic rather than inorganic forms usually reported. The available data on arsenic in fish are presented in Fig. 3 for 23 different fish species and five sampling sites. All data are reported in terms of wet mass. As shown in Fig. 1, concentrations in fish were presented in $\mu \mathrm{g} \mathrm{g}^{-1}$ (wet weight) and ranged from $0.0674 \mu \mathrm{g} \mathrm{g}^{-1}$ in Dammam to $5.54 \mu \mathrm{g} \mathrm{g}^{-1}$ in the coastal area of Bahrain. In the reported data, arsenic levels varied depending on the fish species and sampling locations. The highest arsenic levels were observed in the coastal area of Bahrain in the Southwest (SW) and the Kharg Island in the South East (SE) of the Arabian Gulf. At the Kharg island sampling site, in 12 fish species, arsenic levels exceeded the maximum tolerable limit of $1 \mathrm{ppm}$ recommended by GSO, SASO and SFDA. On the other hand, only three fish species (Cuttle fish, Snapper and Otolithes Ruber) at the Kharg island sampling site contained arsenic in the amounts above the maximum tolerable limit of $3 \mathrm{ppm}$ recommended by the $\mathrm{FAO} / \mathrm{WHO}$ Joint Expert Committee on Food Additives.

Figure $3 b$ shows heavy metal levels at three sampling sites along the Red Sea coastal area. We noted low variation in the As concentration values, as the mean levels of As ranged between 0.18 and 10.04 $\mu \mathrm{g} \mathrm{g}^{-1}$ of wet fish weight. The highest mean arsenicconcentration was recorded for Epinephelus tauvina at the Djeddah site. 


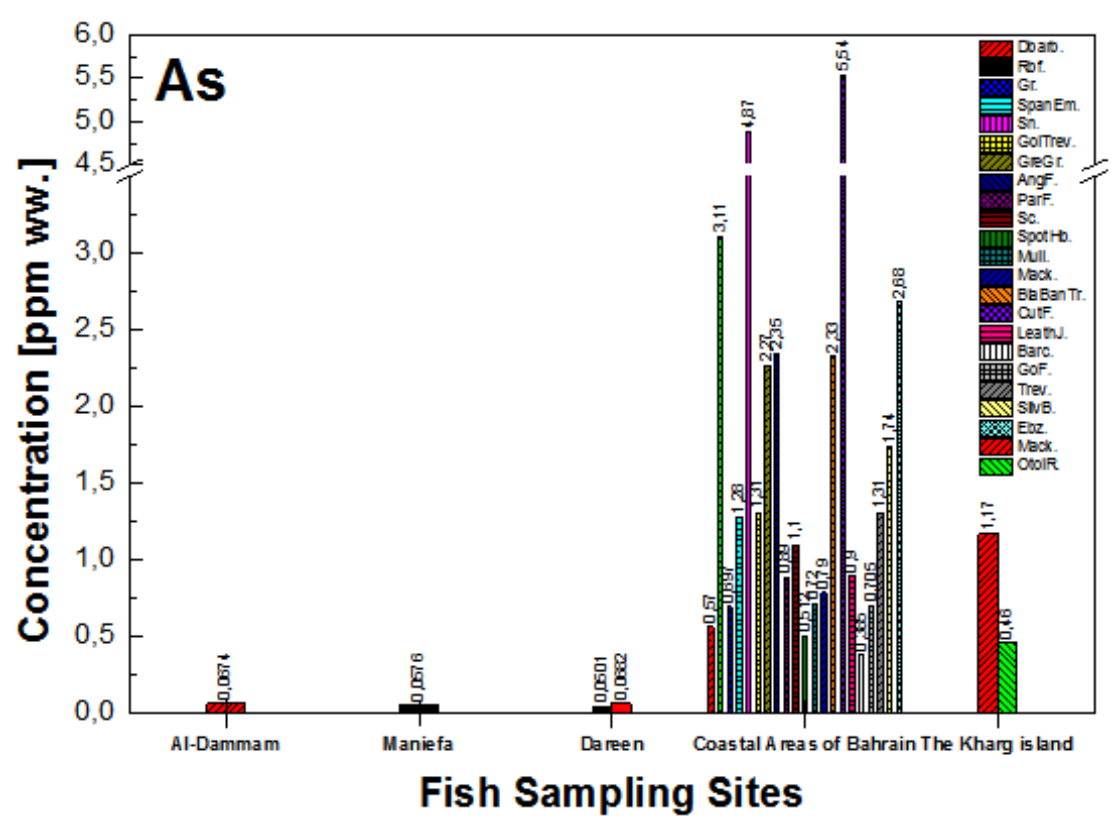

(a)

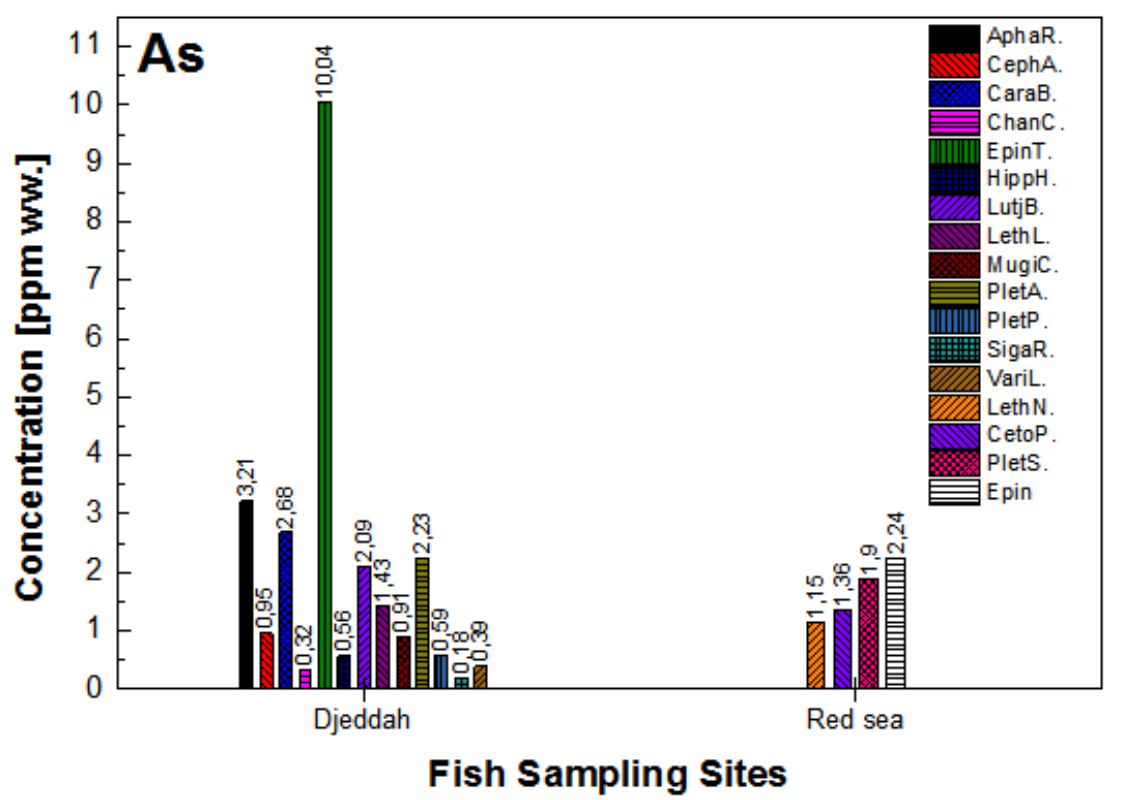

(b)

Fig. 3. Arsenic levels in fish based on literature-reported values for (a) eastern coast of KSA and (b) western coast of KSA. All data are presented in ppm for wet weight (ww)

\section{Cadmium Concentration}

Cadmium is an environmental pollutant and a highly toxic metal that could pose serious threat to the human internal organs (Järup and Åkesson, 2009). It remains in the human body for decades as it cannot be efficiently removed or metabolized. As a result, it may contribute to a variety of illnesses, including heart disease, cancer and diabetes (Järup and Åkesson, 2009). Findings yielded by recent studies (Larsson et al., 2015; Tilley and Fry, 2015; Das et al., 2014) suggest that cadmium exposure may produce adverse health effects at lower exposure levels than previously predicted, including increased risk of hormonal cancers. For example, researchers on Long Island (Gallagher et al., 2010) estimated that about 40\% of breast cancer cases recorded in the U.S. might be associated with elevated cadmium levels. Fish consumption is a dominant route of human exposure. 


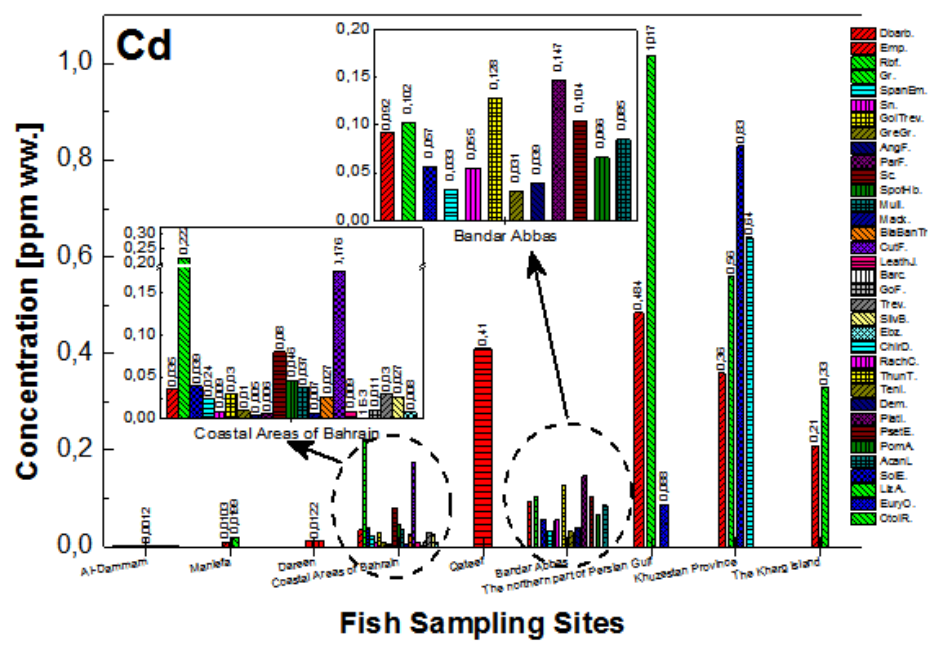

(a)

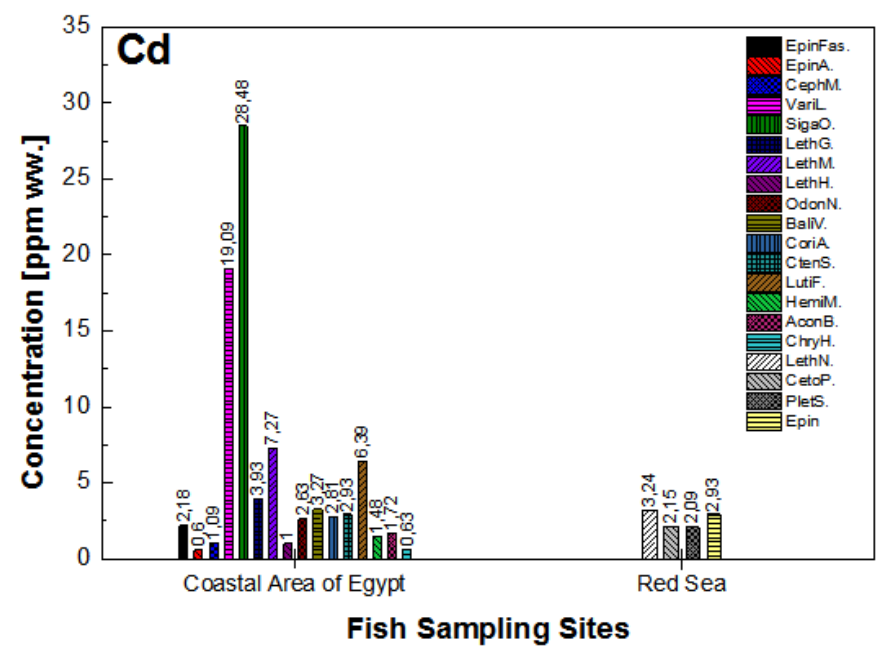

(b)

Fig. 4.Literature-reported cadmium (Cd) levels in (a) eastern coast of KSA and (b) western coast of KSA. The inset plots pertain to the data collected from the coastal area of Bahrain and Bandar Abbas sites. All data are presented in ppm for wet fish weight (ww)

Based on the reported data for the Arabian Gulf, average cadmium levels in 35 fish species from nine sampling sites were calculated, as shown in Fig. 4. The highest cadmium levels are observed in the northern part of the Arabian Gulf for Greasy-grouper with 1.017 ppm. According to the $S A S O$, the maximum tolerable limit for cadmium content in fresh fish is $0.5 \mathrm{ppm}$. In comparison with this standard, at two sampling sitesnorthern part of the Persian Gulf and Khuzestan province, which are located in the Northeast (NE) of the Arabian Gulf-Greasy-grouper, Chirocentrus Dorab and Solea Elongate fish species contain cadmium levels above this threshold.

Figure $4 \mathrm{~b}$ shows the mean concentrations of cadmium in the analyzed fish species in the Red Sea. Levels of Cd ranged between 0.6 and $28.4 \mu \mathrm{g} \mathrm{g}^{-1}$ of wet weight, while the highest mean concentration of cadmium was determined for Siganus oramin in the coastal area of Egypt.

\section{Mercury Concentration}

Mercury is one of the most lethal substances known to man (Graeme and Pollack, 1998; Rana, 2014). It is one of the heavy metals with the highest level of toxicity. It accumulates in the brain, nervous system, heart and kidneys and can cause depression, autoimmune disorders, memory loss, tremors, anemia and heart attacks, among other health issues. A study conducted at the University of Calgary (Seite, 1956) has shown that, when mercury comes into contact with nerve tissue, it can dissolve the myelin sheath that serves as nerve insulation, causing the nerve to disintegrate within 
seconds. Madany et al. (1996) analyzed fresh samples of 21 species of marine fish by electro thermal atomic absorption spectrophotometric method to determine mercury traces in fish tissues. Average concentration ranged from 0.037 to $0.3 \mathrm{ppm}$, as presented in Fig. 5, which is below the European Commission and JECFA recommended limit of $0.5 \mathrm{ppm}$. Another recent study performed by Hosseini et al. (2015) provided mercury concentrations for different fish species caught in Khuzestan province coastal area located in the North East (NE) of the Arabian Gulf. Their findings revealed that the measured mercury concentrations exceeded the $E C$ and the JECFA guidelines for Euryglossa Orientalis, Otolithes Ruber and Psettodes Erumei, at $1.42 \mathrm{ppm}, 0.82 \mathrm{ppm}$ and $0.61 \mathrm{ppm}$, respectively (Fig. 5).

Figure $5 \mathrm{~b}$ shows the mean $\mathrm{Hg}$ concentrations in the analyzed fish species in the Red Sea. The average concentration ranged from 0.00 to $0.51 \mathrm{ppm}$. With the value of $0.51 \mu \mathrm{g} \mathrm{g}^{-1}$ of wet weight, Plectorhynchus schotaf exhibited the highest mean values for mercury, whereas Siganus rivulatus had the lowest mean values at $0.02 \mu \mathrm{g} \mathrm{g}^{-1}$ of wet weight.

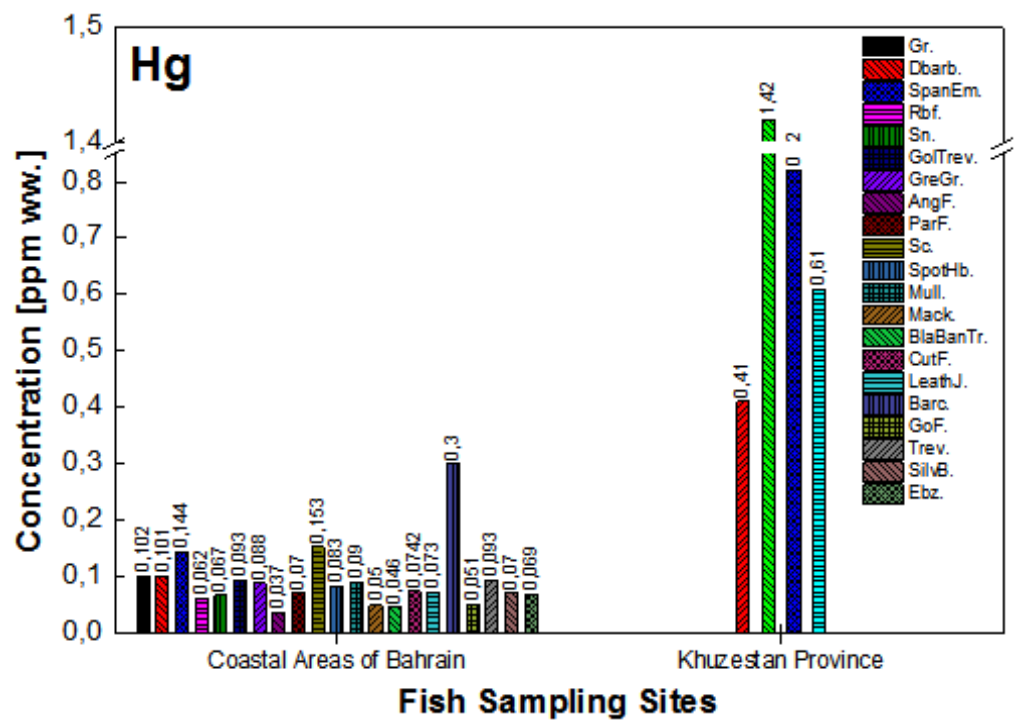

(a)

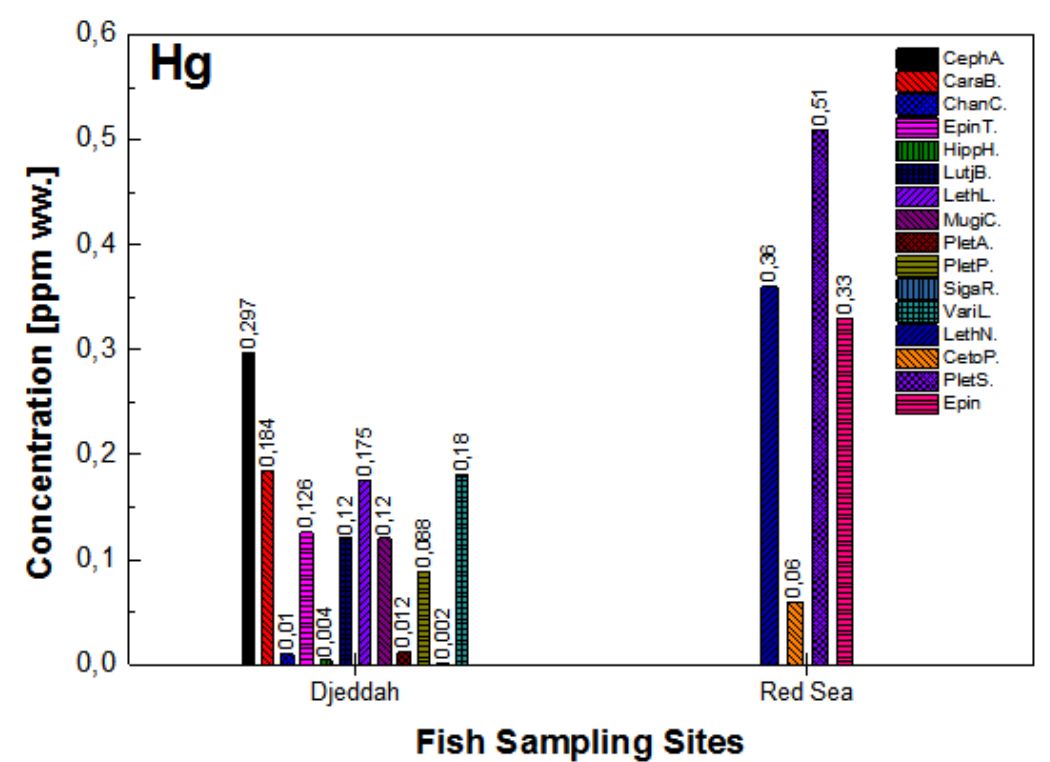

(b)

Fig. 5. Literature-reported mercury (Hg) levels in (a) Eastern coast of KSA and (b) Western coast of KSA. All data are presented in ppm for wet fish weight (ww) 


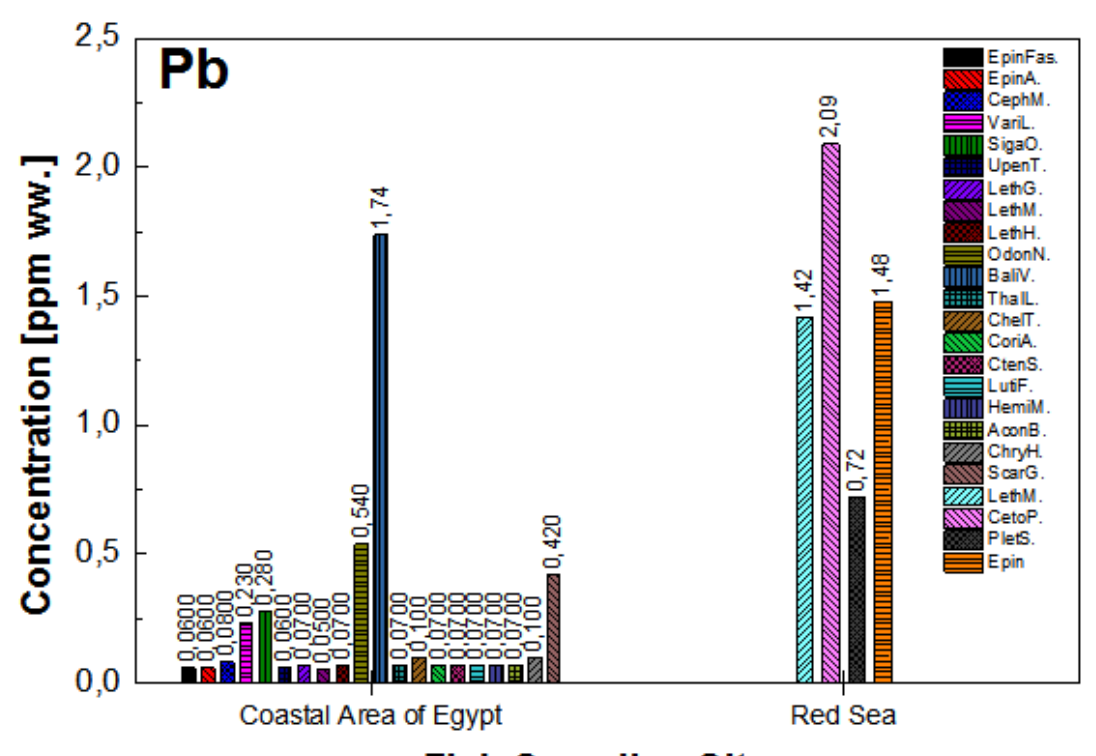

Fish Sampling Sites

Fig. 6. Literature-reported lead $(\mathrm{Pb})$ levels in fish caught along the Western coast of KSA. All data are presented in ppm for wet fish weight (ww)

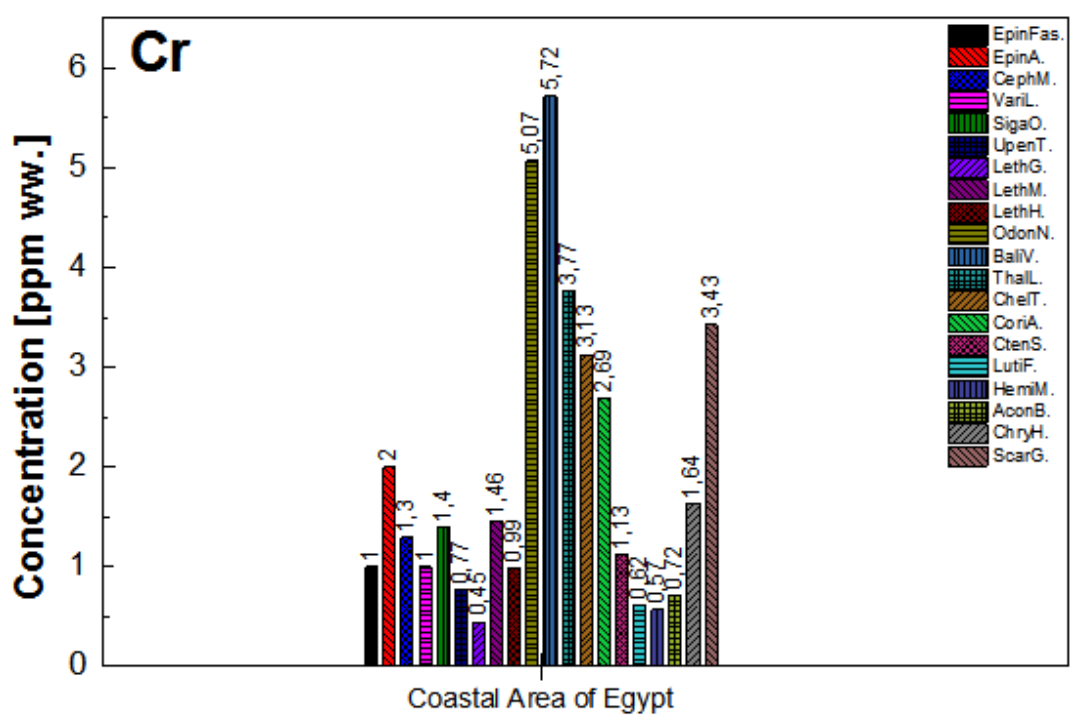

Fish Sampling Sites

Fig. 7. Literature-reported chromium $(\mathrm{Cr})$ levels in the fish species caught along the western coast of KSA. All data are presented in ppm for wet fish weight (ww)

As shown in Fig. 6, lead concentrations varied significantly between the two Red Sea sites. The mean $\mathrm{Pb}$ concentration in different fish species ranges between 0.05 and $2.09 \mathrm{ppm}$ on the wet weight basis. The highest and the lowest mean level of lead on the wet weight basis was observed in Cetoscarus pulchellus and Lethrinus mahsena, with 2.09 and $0.05 \mu \mathrm{g} \mathrm{g} \mathrm{g}^{-1}$, respectively. Lead concentrations in the fish samples analyzed in the study conducted by Al-Ghanim et al.
(2015) were much higher (except Balistoides Vridiscens) than those observed in the study of Hanna.

\section{Chromium Concentration}

Chromium levels in the examined samples ranged from $0.57 \mathrm{ppm}$ to $5.72 \mathrm{ppm}$ on the wet weight basis. Among the analyzed samples, Balistoides Vridiscens shows the highest mean concentration of chromium (Fig. 7). 


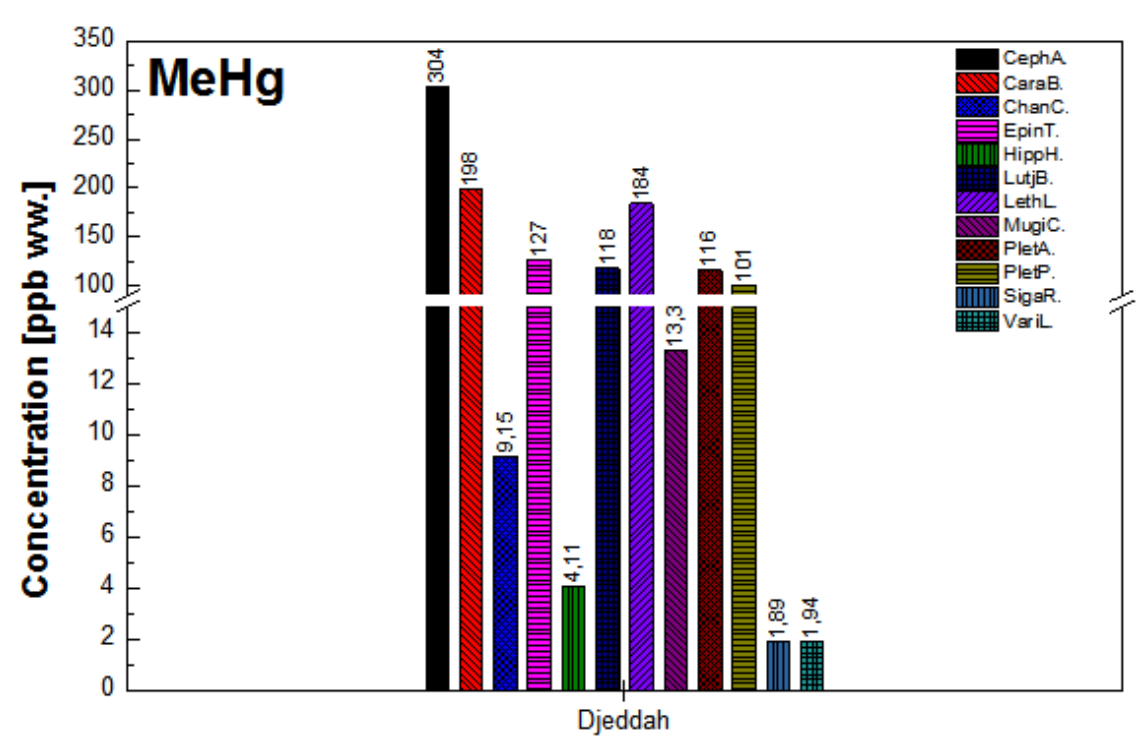

Fish Sampling Sites

Fig. 8. Literature-reported methylmercury $(\mathrm{MeHg})$ levels in fish species along the western coast of KSA. All data are presented in ppm for wet fish weight (ww)

\section{Methylmercury Concentration}

Methylmercury is the most important form of mercury in terms of toxicity and adverse health effects due to environmental exposure (Järup, 2003). Unfortunately, literature pertinent to the determination of this heavy metal concentration in fish is limited. As shown in Fig. 8, Cephalopholis argus exhibited the highest mean methylmercury values, while Siganus rivulatus showed the lowest mean values for both mercury and methylmercury (Burger et al., 2014b).

\section{Risk Assessment}

\section{Hazard identification}

In the $1930 \mathrm{~s}$, the Chisso Chemical Corporation built a factory in Minamata, located in southwest Japan. It was erected between the Minamata River and the Minamata Bay. It produced chemicals such as acetaldehyde $\left(\mathrm{CH}_{3} \mathrm{CHO}\right)$, which is not inherently dangerous. It is used as a precursor for a chemical reaction required for obtaining vinegar. However, the processes employed were based on an enzyme that contained heavy metal traces, including mercury. As this factory released waste products directly into the bay, methylmercury entered the food chain. These methylmercury traces gradually propagated through the food chain and could be found in fish caught for human consumption. Local residents started to develop the Minamata disease, the cause of which was eventually traced to this factory. Over 2,000 people developed the Minamata disease before this link was established. This case raised awareness of pollutants that enter ecosystems, as many can result in disease. While exposure to harmful products can result in a chronic disease, health issues could also be acute. Chronic and acute diseases can also be induced by pollution. In other words, heavy metal traces that enter the environment become toxic substances with serious consequences for human health. According to the WHO, based on their human health mechanisms of toxicity, toxins can be classified as: (1) Carcinogens, which are probably the best know toxin substances, as they are cancer-causing chemicals that disrupt the human cellular metabolic processes; (2) neurotoxins, which attack the brain and the nervous system and tissues; (3) teratogens, as they lead to congenital anomalies in an embryo or fetus, manifesting as dextrocardia disease; (4) endocrine disruptors, which impact the endocrine system or hormones; and (5) allergens that cause an allergic reaction. Table 5 provides a summary on heavy metal and metalloid classification, along with their human risks for oral route of exposure, which is relevant to fish consumption. As shown in Table 5, arsenic, mercury and methylmercury are neurotoxins that are usually present in doses exceeding safe limits. These toxins can damage parts of the brain, especially the prefrontal cortex.

\section{Hazard Characterization}

To conduct a comprehensive risk assessment process, safety factor approach is used for establishing acceptable and tolerable intakes of heavy metals for which toxicity thresholds are established. These safe intake levels are recommended by local (SASO, SFDA), regional (GSO) 
and international (EC, FAO, WHO, JECFA) institutions, as shown in Table 1. However, tolerable maximum limits have not yet been established for all heavy metals. As heavy metals accumulate in the human body, JECFA uses the term PTWI, or provisional tolerable weekly intake, to highlight the importance of limiting exposure over a fixed period of time. PTWI values for the most common heavy metals are presented in Table 1.

Table 5. Heavy metal health adverse effects and corresponding toxicological category

\begin{tabular}{|c|c|c|c|c|c|}
\hline \multirow[b]{2}{*}{ Heavy Metal } & \multirow{2}{*}{$\begin{array}{l}\text { Adverse effect on } \\
\text { human health }\end{array}$} & \multicolumn{4}{|c|}{ Toxicological category } \\
\hline & & Neurotoxin & Carcinogen & Teratogen & Endocrine disruptors \\
\hline $\begin{array}{l}\text { Arsenic } \\
\text { (CAS: } 7440-38-2)\end{array}$ & $\begin{array}{l}\text { - Cardiovascular and peripheral vascular disease } \\
\text { - Developmental anomalies } \\
\text { - Neurologic and neuro-behavioral disorders } \\
\text { - Diabetes } \\
\text { - Hearing loss } \\
\text { - Hematologic disorders } \\
\text { - Cancer: lung, bladder, skin, encephalopathy }\end{array}$ & $\sqrt{ }$ & $\sqrt{ }$ & & \\
\hline $\begin{array}{l}\text { Cadmium } \\
\text { (CAS: } 7440-43-9)\end{array}$ & $\begin{array}{l}\text { - Lung cancer } \\
\text { - Proteinuria } \\
\text { - Osteomalacia } \\
\text { - Non-descended testes in young males }\end{array}$ & $\sqrt{ }$ & & $\sqrt{ }$ & \\
\hline $\begin{array}{l}\text { Lead } \\
\text { (CAS: 7439-92-1) }\end{array}$ & $\begin{array}{l}\text { - Encephalopathy } \\
\text { - Abdominal pain } \\
\text { - Nephropathy } \\
\text { - Foot-drop/ wrist-drop }\end{array}$ & & & & \\
\hline $\begin{array}{l}\text { Mercury } \\
\text { (CAS: 7439-97-6) }\end{array}$ & $\begin{array}{l}\text { - Nausea } \\
\text { - Gingivo-stomatitis } \\
\text { - Tremor } \\
\text { - Neurasthenia } \\
\text { - Nephrotic syndrome } \\
\text { - Gastrointestinal toxicity }\end{array}$ & $\sqrt{ }$ & $\sqrt{ }$ & & \\
\hline $\begin{array}{l}\text { Chromium } \\
\text { (CAS: } 7440-47-3 \text { ) }\end{array}$ & $\begin{array}{l}\text { - Pulmonary fibrosis } \\
\text { - Lung cancer (inhalation) } \\
\text { - Cardiovascular, renal, gastrointestinal, } \\
\text { hematological and neurological effects }\end{array}$ & $\sqrt{ }$ & $\sqrt{ }$ & & \\
\hline $\begin{array}{l}\text { Nickel } \\
\text { (CAS: 7440-02-0) }\end{array}$ & $\begin{array}{l}\text { - Occupational (inhaled): Pulmonary fibrosis, } \\
\text { reduced sperm count, nasopharyngeal tumors }\end{array}$ & $\sqrt{ }$ & & $\sqrt{ }$ & \\
\hline $\begin{array}{l}\text { Methyl-mercury } \\
\text { (CAS:22967-92-6) }\end{array}$ & $\begin{array}{l}\text { - Harmful to infant's developing nervous system } \\
\text { - Damage the fetus } \\
\text { - Nephrotoxicity and gastrointestinal toxicity }\end{array}$ & $\sqrt{ }$ & & $\sqrt{ }$ & \\
\hline
\end{tabular}

\section{Exposure Assessment Equations}

To assess the impact of hazardous heavy metals on human health, authors of extant studies have adopted several calculation approaches (Ravankhah et al., 2016; $\mathrm{Xu}$ et al., 2016; Pelfrêne et al., 2014; Dumitrescu et al., 2012) based on the exposure estimation to a metal by oral ingestion. This oral exposure is expressed as the Average Daily Dose $(A D D)$ in $\mathrm{mg} \mathrm{kg}^{-1} \mathrm{day}^{-1}$ using the following expression:

$A D D=\frac{C_{m} \times C_{F} \times I R \times E F \times E D_{T o t}}{B W \times \overline{A T}}$

where, $C_{m}$ is the investigated metal concentration in fresh fish (ppm wet weight), $C_{F}$ is the conversion factor from wet to dry weight $(0.33)$, IR is the ingestion rate ( $g$ person $^{-1}$ day $\left.^{-1}\right), E F$ is the exposure frequency over the average lifetime (365.25 days year ${ }^{-1}$ ), $E D_{\text {Tot }}$ is the total exposure duration over the average lifetime (74.34 years as life expectancy for individuals in Saudi Arabia), BW is the body weight (73 kg for an 74.34-year-old individual) and $\overline{A T}$ is the average exposure time over the average lifetime (365.25 day/year $\times 74.34$ years). In order to calculate the $A D D$ correctly, $I R$ should be estimated using an exact consumption pattern for fish by individuals. This consumption pattern depends on several parameters, including fish species, frequency of consumption of particular species (average meal size), age category and gender. In a recent study, Burger et al. (2015) carried out a survey of 975 households and concluded that Saudis were eating 2.2 fish-based meals/week, whereby Grouper fish (including both Epinephelus and Cephalopholis) was most widely consumed, followed by Plectropomus pessuliferus, Hipposcarus harid and Lethrinus lentjan. 
In contrast to this survey-based approach, four standard exposure scenarios are adopted (US EPA) in the present study.

Equation 1 is only suitable for non-carcinogen estimation of ADD. As shown in Table 5, most of heavy metals and metalloids are categorized as carcinogenic substances. Hence, to investigate the increased cancer risk from a lifetime oral exposure to a heavy metal agent, the following equation is used:

$C R=\frac{C_{m} \times C_{F} \times I R \times E F \times E D_{T o t} \times C S F}{B W \times \overline{A T}}$

where, CSF is the carcinogenic oral slope factor, which depends on the metal type. CFS can be estimated from the integrated risk information system database for different metals.

Heavy metal Hazard Index (HI) can be estimated for each metal type by using the following equation:

$H I=\frac{A D D}{O R_{f} D}$

where, $O R_{f} D$ is the oral reference dose $\left(\mathrm{mg}^{-1} \mathrm{~kg}^{-1} \mathrm{day}^{-1}\right)$.

\section{Risk Characterization (Potential for Human Exposure)}

Based on all studies selected for review; Fig. 9a shows the number of samples that exceeded the permissible limit for the Arabian Gulf and Red Sea fish sampling sites. Maximum allowed limits were recommended by national (SASO, SFDA), regional (GSO) and international institutions (WHO, FAO, JECFA). In the studies conducted on western Saudi
Arabian coast, 40 samples exceed permissible limit for all metals, which corresponds to $11.76 \%$ of all analyzed fish samples. More specifically, $\mathrm{As}, \mathrm{Cd}$ and $\mathrm{Pb}$ concentrations were above the limit in 10, 20 and 9 fish samples, respectively. The mercury levels were higher than the $0.5 \mu \mathrm{g} \mathrm{g}^{-1}$ wet wt. limit proposed by EC (Regulations No 1881/2006 and No 629/2008) and JECFA (FAO/WHO Joint Expert Committee on Food Additives) for only one sample (Plectorhynchus schotaf). In sum, the Red Sea sampling site seems to be the most contaminated among the three studied areas. Among the 16 examined samples, 13 exceed permissible limit. This finding is confirmed by the radar plot in Fig. 9b.

On the eastern Saudi Arabian coast, 413 fish samples (36 fish species) were collected from nine different fish sampling sites. Figure $10 \mathrm{~b}$ provides the number of samples above the permissible limit for these studied sites. As it can be seen, for heavy metals, there were significant differences in the number of samples that exceeded the permissible limits across the six investigated sites. Moreover, about $15 \%$ of the analyzed samples (40 samples) exceed permissible limit of different heavy metals. Specifically, at all sites, some samples (1 to 9 samples) contained $\mathrm{Pb}$ levels that exceeded the permissible limit of $0.2 \mu \mathrm{g} \mathrm{g}^{-1}$ provided by 2 JECFA (FAO/WHO Joint Expert Committee on Food Additives). Regarding mercury, only three fish species (Euryglossa orientalis, Otolithes ruber and Psettodes erumei) with $\mathrm{Hg}$ levels higher than the allowed limit (0.5 ppm, wet weight) were detected at the Khuzestan Province site. In addition, at this site, some samples where characterized by exceedence for four of the five heavy metals investigated in this study.

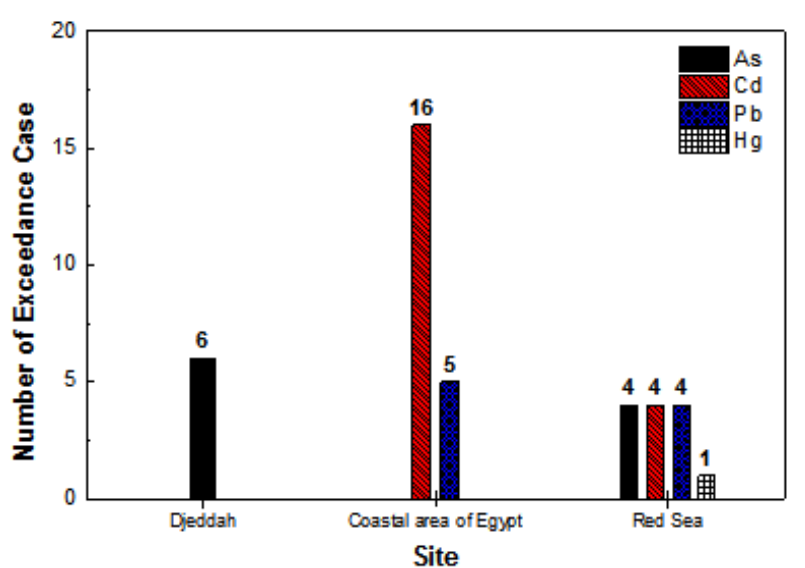

(a)

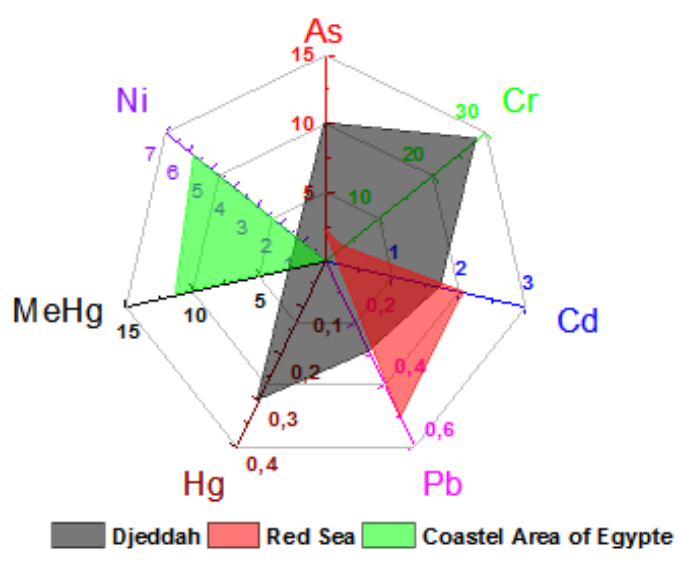

(b)

Fig. 9. Number of exceedance cases (a) and maximum metal concentrations (b) in fish caught at Saudi western sites 


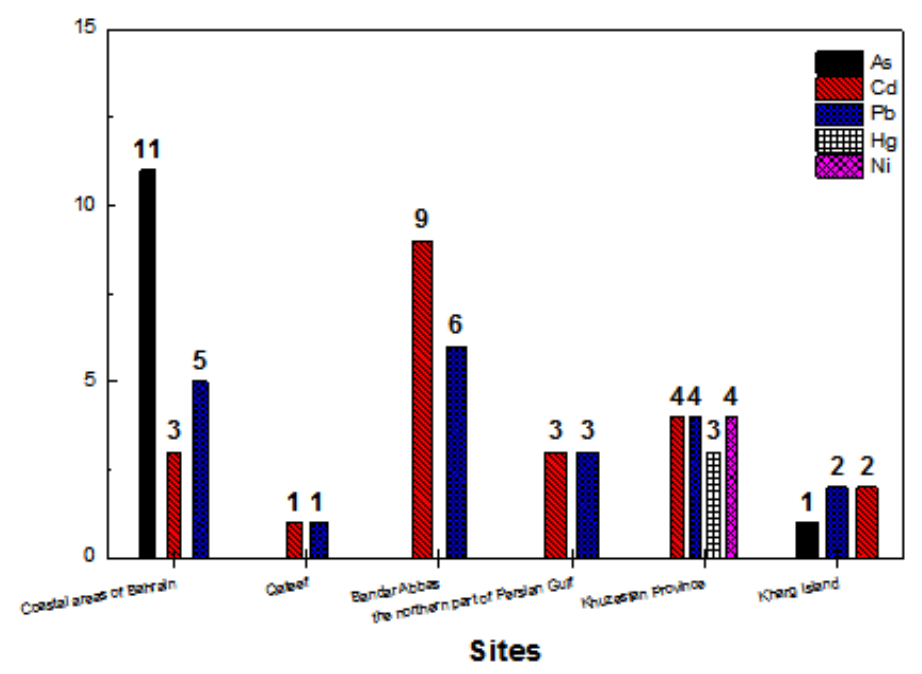

(a)

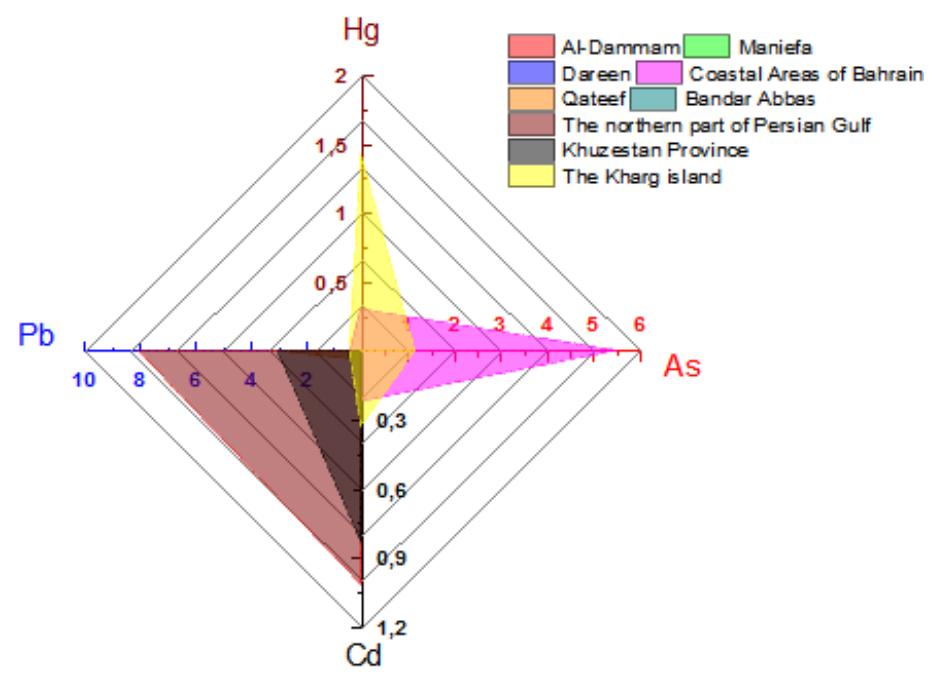

(b)

Fig. 10. Number of exceedance cases (a) and maximum metal concentrations (b) in fish for Saudi Eastern sites

Table 6. Scenario 1, high fish consumption/high metal concentration $(I R=250)$

\begin{tabular}{|c|c|c|c|c|c|c|c|c|c|c|c|c|c|c|c|c|c|c|}
\hline \multirow[b]{3}{*}{ Metal } & \multicolumn{18}{|c|}{ Western Coastal Areas } \\
\hline & \multicolumn{3}{|c|}{ Djeddah Coastal } & \multicolumn{3}{|c|}{ Area of Egypt } & \multicolumn{3}{|c|}{ Red Sea } & & & & & & & & & \\
\hline & FS & $\mathrm{C}_{\mathrm{M}}$ & $\mathrm{HI}$ & FS & $\mathrm{C}_{\mathrm{M}}$ & $\mathrm{HI}$ & FS & $\mathrm{C}_{\mathrm{M}}$ & $\mathrm{HI}$ & & & & & & & & & \\
\hline$\overline{A s}$ & EpinT. & 10.04 & 37.82 & -- & -- & -- & Epin & 2.24 & 8.43 & & & & & & & & & \\
\hline $\mathrm{Hg}$ & -- & -- & -- & -- & -- & -- & PletS. & 0.51 & 1.92 & & & & & & & & & \\
\hline $\mathrm{Pb}$ & -- & -- & -- & BaliV. & 1.74 & 0.49 & CetoP. & 2.09 & 0.59 & & & & & & & & & \\
\hline \multirow[t]{3}{*}{$C d$} & -- & -- & -- & SigaO. & 28.48 & 32.18 & LethN. & 3.24 & 3.66 & & & & & & & & & \\
\hline & \multicolumn{18}{|c|}{ Eastern Coastal Areas } \\
\hline & \multicolumn{6}{|c|}{$\begin{array}{l}\text { Coastal Area of } \\
\text { Bahrain }\end{array}$} & \multicolumn{3}{|c|}{ Bandar Abbas } & \multicolumn{3}{|c|}{ The northern part } & \multicolumn{3}{|c|}{$\begin{array}{l}\text { Khuzestan Province } \\
\text { of Persian Gulf }\end{array}$} & \multicolumn{3}{|c|}{ Kharg Island } \\
\hline Metal & FS & $\mathrm{C}_{\mathrm{M}}$ & $\mathrm{HI}$ & FS & $\mathrm{C}_{\mathrm{M}}$ & $\mathrm{HI}$ & FS & $\mathrm{C}_{\mathrm{M}}$ & $\mathrm{HI}$ & FS & $\mathrm{C}_{\mathrm{M}}$ & $\mathrm{HI}$ & FS & $\mathrm{C}_{\mathrm{M}}$ & $\mathrm{HI}$ & FS & $\mathrm{C}_{\mathrm{M}}$ & $\mathrm{HI}$ \\
\hline As & CutF. & 5.54 & 20.86 & -- & -- & -- & -- & -- & -- & -- & -- & -- & -- & -- & -- & Mack. & 1.17 & 4.40 \\
\hline$H g$ & -- & -- & -- & -- & -- & -- & -- & -- & -- & -- & -- & -- & EuryO. & 1.42 & 5.34 & -- & -- & -- \\
\hline $\mathrm{Pb}$ & Barc. & 0.39 & -- & EpinM. & 3.19 & 0.9 & AcanL & 0.534 & 0.15 & PsetE. & 8.02 & 2.26 & EuryO. & 3.01 & 0.85 & Mack. & 0.41 & 0.11 \\
\hline$C d$ & $G r$ & 0.222 & 0.25 & EpinM & 0.41 & 0.46 & PlatI. & 0.147 & 0.16 & PsetE. & 1.017 & 1.14 & EuryO. & 0.83 & 0.93 & OtolR. & 0.33 & 0.37 \\
\hline$N i$ & -- & -- & -- & -- & -- & -- & -- & -- & -- & -- & -- & -- & EuryO. & 63.02 & 3.56 & -- & -- & -- \\
\hline
\end{tabular}


Othman M. Hakami / American Journal of Environmental Sciences 2016, 12 (6): 341.357 DOI: 10.3844/ajessp.2016.341.357

\begin{tabular}{|c|c|c|c|c|c|c|c|c|c|c|c|c|c|c|c|c|c|c|}
\hline \multirow[b]{3}{*}{ Metal } & \multicolumn{18}{|c|}{ Western Coastal Areas } \\
\hline & \multicolumn{3}{|c|}{ Djeddah } & \multicolumn{3}{|c|}{ Coastal Area of Egypt } & \multicolumn{3}{|l|}{ Red Sea } & & & & & & & & & \\
\hline & FS & $\mathrm{C}_{\mathrm{M}}$ & $\mathrm{HI}$ & FS & $\mathrm{C}_{\mathrm{M}}$ & $\mathrm{HI}$ & FS & $\mathrm{C}_{\mathrm{M}}$ & $\mathrm{HI}$ & & & & & & & & & \\
\hline As & LethL. & 1.43 & 5.38 & -- & -- & -- & LethN. & 1.15 & 4.33 & & & & & & & & & \\
\hline$H g$ & -- & -- & -- & -- & -- & -- & CetoP. & 0.06 & 0.22 & & & & & & & & & \\
\hline $\mathrm{Pb}$ & -- & -- & -- & VariL. & 0.23 & 0.064 & PletS. & 0.72 & 0.20 & & & & & & & & & \\
\hline \multirow[t]{3}{*}{$C d$} & -- & -- & -- & EpinA. & 0.6 & 0.67 & PletS. & 2.09 & 2.36 & & & & & & & & & \\
\hline & \multicolumn{18}{|c|}{ Eastern Coastal Areas } \\
\hline & \multicolumn{3}{|c|}{$\begin{array}{l}\text { Coastal Area } \\
\text { of Bahrain }\end{array}$} & \multicolumn{3}{|l|}{ Qateef } & \multicolumn{3}{|c|}{ Bandar Abbas } & \multicolumn{3}{|c|}{$\begin{array}{l}\text { The northern part } \\
\text { of Persian Gulf }\end{array}$} & \multicolumn{3}{|c|}{ Khuzestan Province } & \multicolumn{3}{|c|}{ Kharg Island } \\
\hline Metal & FS & $\mathrm{C}_{\mathrm{M}}$ & $\mathrm{HI}$ & FS & $\mathrm{C}_{\mathrm{M}}$ & $\mathrm{HI}$ & FS & $\mathrm{C}_{\mathrm{M}}$ & $\mathrm{HI}$ & FS & $\mathrm{C}_{\mathrm{M}}$ & $\mathrm{HI}$ & FS & $\mathrm{C}_{\mathrm{M}}$ & $\mathrm{HI}$ & FS & $\mathrm{C}_{\mathrm{M}}$ & $\mathrm{HI}$ \\
\hline As & Sc. & 1.1 & 4.14 & -- & -- & -- & -- & -- & -- & -- & -- & -- & -- & -- & -- & Mack. & 1.17 & 4.40 \\
\hline $\mathrm{Hg}$ & -- & -- & -- & -- & -- & -- & -- & -- & -- & -- & -- & -- & PsetE. & 0.61 & 2.29 & - & -- & -- \\
\hline $\mathrm{Pb}$ & SilvB. & 0.21 & 0.05 & EpinM. & 3.19 & 0.9 & PlatI. & 0.211 & 0.05 & Mack. & 2.8 & 0.79 & LizA. & 2.11 & 0.59 & OtolR. & 0.28 & 0.07 \\
\hline$C d$ & Sc. & 0.8 & 0.9 & SilvB. & 0.41 & 0.46 & RachC. & 0.055 & 0.006 & SolE. & 0.088 & 0.09 & PsetE. & 0.36 & 0.4 & Mack. & 0.21 & 0.23 \\
\hline $\mathrm{Ni}$ & -- & -- & -- & -- & -- & -- & -- & -- & -- & -- & -- & -- & PsetE. & 53.12 & 3 & -- & -- & -- \\
\hline
\end{tabular}

Table 8. Scenario 3, average fish consumption/high metal concentration $(\mathrm{IR}=90.58)$ Western Coastal Areas

\begin{tabular}{|c|c|c|c|c|c|c|c|c|c|c|c|c|c|c|c|c|c|c|}
\hline \multirow[b]{2}{*}{ Metal } & \multicolumn{2}{|c|}{ Djeddah } & \multirow{2}{*}{$\begin{array}{l}\text { Coastal } \\
\text { HI } \\
\end{array}$} & \multicolumn{2}{|c|}{ Area of Egypt } & \multicolumn{4}{|c|}{ Red Sea } & & & & & & & & & \\
\hline & FS & $\mathrm{C}_{\mathrm{M}}$ & & FS & $\mathrm{C}_{\mathrm{M}}$ & $\mathrm{HI}$ & FS & $\mathrm{C}_{\mathrm{M}}$ & $\mathrm{HI}$ & & & & & & & & & \\
\hline As & EpinT. & 10.04 & 14.19 & -- & -- & -- & Epin & 2.24 & 3.05 & & & & & & & & & \\
\hline$H g$ & -- & -- & -- & -- & -- & -- & PletS. & 0.51 & 0.69 & & & & & & & & & \\
\hline$P b$ & -- & -- & -- & BaliV. & 1.74 & 0.17 & CetoP. & 2.09 & 0.21 & & & & & & & & & \\
\hline \multirow[t]{3}{*}{$C d$} & -- & -- & -- & SigaO. & 28.48 & 11.66 & LethN. & 3.24 & 0.33 & & & & & & & & & \\
\hline & \multicolumn{18}{|c|}{ Eastern Coastal Areas } \\
\hline & \multicolumn{3}{|c|}{$\begin{array}{l}\text { Coastal Area } \\
\text { of Bahrain }\end{array}$} & \multicolumn{3}{|l|}{ Qateef } & \multicolumn{3}{|c|}{ Bandar Abbas } & \multicolumn{3}{|c|}{$\begin{array}{l}\text { The northern part } \\
\text { of Persian Gulf }\end{array}$} & \multicolumn{3}{|c|}{ Khuzestan Province } & \multicolumn{3}{|c|}{ Kharg Island } \\
\hline Metal & FS & $\mathrm{C}_{\mathrm{M}}$ & $\mathrm{HI}$ & FS & $\mathrm{C}_{\mathrm{M}}$ & $\mathrm{HI}$ & FS & $\mathrm{C}_{\mathrm{M}}$ & $\mathrm{HI}$ & FS & $\mathrm{C}_{\mathrm{M}}$ & HI & FS & $\mathrm{C}_{\mathrm{M}}$ & HI & FS & $\mathrm{C}_{\mathrm{M}}$ & $\mathrm{HI}$ \\
\hline As & CutF. & 5.54 & 7.56 & -- & -- & -- & -- & -- & -- & -- & -- & -- & -- & -- & -- & Mack. & 1.17 & 1.59 \\
\hline $\mathrm{Hg}$ & -- & -- & -- & -- & -- & -- & -- & -- & -- & -- & -- & -- & EuryO. & 1.42 & 1.93 & -- & -- & -- \\
\hline $\mathrm{Pb}$ & Barc. & 0.39 & 0.039 & EpinM. & 3.19 & 0.32 & AcanL & 0.534 & 0.05 & PsetE. & 8.02 & 0.82 & EuryO. & 3.01 & 0.3 & Mack. & 0.41 & 0.04 \\
\hline$C d$ & $G r$ & 0.222 & 0.09 & EpinM. & 0.41 & 0.16 & PlatI. & 0.147 & 0.06 & PsetE. & 1.017 & 0.41 & EuryO. & 0.83 & 0.33 & OtolR. & 0.33 & 0.13 \\
\hline $\mathrm{Ni}$ & -- & -- & -- & -- & -- & -- & -- & -- & -- & -- & -- & -- & EuryO. & 63.02 & 1.29 & -- & -- & -- \\
\hline
\end{tabular}

Table 9:Scenario 4,average fish consumption/average metal concentration $(\mathrm{IR}=90.58)$

\begin{tabular}{|c|c|c|c|c|c|c|c|c|c|c|c|c|c|c|c|c|c|c|}
\hline \multirow[b]{3}{*}{ Metal } & \multicolumn{9}{|c|}{ Western Coastal Areas } & & & & & & & & & \\
\hline & \multicolumn{3}{|c|}{ Djeddah } & \multicolumn{3}{|c|}{ Coastal Area of Egypt } & \multicolumn{3}{|l|}{ Red Sea } & & & & & & & & & \\
\hline & FS & $\mathrm{C}_{\mathrm{M}}$ & $\mathrm{HI}$ & FS & $\mathrm{C}_{\mathrm{M}}$ & HI & FS & $\mathrm{C}_{\mathrm{M}}$ & $\mathrm{HI}$ & & & & & & & & & \\
\hline$\overline{A s}$ & LethL. & 1.43 & 1.95 & -- & -- & -- & LethN. & 1,15 & 1.56 & & & & & & & & & \\
\hline$H g$ & -- & -- & -- & -- & -- & -- & CetoP. & 0,06 & 0.08 & & & & & & & & & \\
\hline $\mathrm{Pb}$ & -- & -- & -- & VariL. & 0.23 & 0.02 & PletS. & 0,72 & 0.07 & & & & & & & & & \\
\hline \multirow[t]{3}{*}{$C d$} & -- & -- & -- & EpinA. & 0,6 & 0.24 & PletS. & 2,09 & 0.85 & & & & & & & & & \\
\hline & \multicolumn{18}{|c|}{ Eastern Coastal Areas } \\
\hline & \multicolumn{3}{|c|}{$\begin{array}{l}\text { Coastal Area } \\
\text { of Bahrain }\end{array}$} & \multicolumn{3}{|l|}{ Qateef } & \multicolumn{3}{|c|}{ Bandar Abbas } & \multicolumn{3}{|c|}{$\begin{array}{l}\text { The northern part of } \\
\text { Persian Gulf }\end{array}$} & \multicolumn{3}{|c|}{ Khuzestan Province } & \multicolumn{3}{|c|}{ Kharg Island } \\
\hline Metal & FS & $\mathrm{C}_{\mathrm{M}}$ & $\mathrm{HI}$ & FS & $\mathrm{C}_{\mathrm{M}}$ & $\mathrm{HI}$ & FS & $\mathrm{C}_{\mathrm{M}}$ & $\mathrm{HI}$ & FS & $\mathrm{C}_{\mathrm{M}}$ & $\mathrm{HI}$ & FS & $\mathrm{C}_{\mathrm{M}}$ & $\mathrm{HI}$ & FS & $\mathrm{C}_{\mathrm{M}}$ & $\mathrm{HI}$ \\
\hline As & Sc. & 1.1 & 1.5 & -- & -- & -- & -- & -- & -- & -- & -- & -- & -- & -- & -- & Mack. & 1.17 & 1.59 \\
\hline $\mathrm{Hg}$ & -- & -- & -- & -- & -- & -- & -- & -- & -- & -- & -- & -- & PsetE. & 0.61 & 0.83 & -- & -- & -- \\
\hline $\mathrm{Pb}$ & SilvB. & 0.21 & 0.02 & EpinM. & 3.19 & 0.32 & PlatI. & 0.211 & 0.02 & Mack. & 2.8 & 0.28 & LizA. & 2.11 & 0.21 & OtolR. & 0.28 & 0.02 \\
\hline$C d$ & Sc. & 0.8 & 0.32 & SilvB. & 0.41 & 0.16 & RachC. & 0.055 & 0.02 & SolE. & 0.088 & 0.03 & PsetE. & 0.36 & 0.14 & Mack. & 0.21 & 0.08 \\
\hline $\mathrm{Ni}$ & -- & -- & -- & -- & -- & -- & -- & -- & -- & -- & -- & -- & PsetE. & 53.12 & 1.08 & -- & -- & -- \\
\hline
\end{tabular}

Using Equation 1 and 3, $A D D$ and $H I$ are calculated for all the exceedance cases based on four exposure scenarios for high and average fish consuming populations (Table 6-9). The calculated HI values reveal 
that arsenic presents the greatest risk for adverse health effects $(\mathrm{HI}>10)$ for high and average consuming populations of Epinephelus Tauvina and Cuttle fish species caught in Djeddah and coastal area of Bahrain sites, respectively. Moreover, there is a high probability that cadmium would induce adverse health effects for high and average consuming populations of Siganus Oramin fish caught in Coastal Area of Egypt. It should be noted that $\mathrm{HI}>1$ indicates that adverse health effects are possible, although not assured. Conversely, HI $<1$ implies that no adverse effects are expected as a result of exposure. Hence, big consumers of Epinephelus Tauvina and Cuttle fish species caught in Jeddah (Saudi Arabia) and coastal area of Bahrain sites ingest high doses of arsenic and can experience the appearance of pattern of skin changes for a long time exposure. Absorbing arsenic has also been reported to increase the risk of cancer in the liver, bladder and lungs. On the other hand, big consumers of Siganus Oramin fish, caught in coastal area of Egypt, are exposed to high level of cadmium contamination that can causes birth defects and affects the skeleton in the developing young. This risk assessment study can serve as a status report for policy makers to limit industrial discharges in common coastal fishing areas and to prohibit fishing in contaminated areas. A consumption advisory can be established by Saudi national health regulatory and standardization organizations, i.e., the Ministry of Health (MOH) as a recommendation to limit or avoid eating these heavy metal contaminated fish species in these areas and to raise the population awareness about their consumption.

\section{Conclusion}

Over the recent years, the consumption of different types of fish by Saudi Arabian population has increased. Consequently, the intake of trace elements, especially heavy metals, through fish consumption has become of high concern for human health. Mean concentrations of arsenic, cadmium, mercury, lead, chromium and methylmercury were collected from 11 peer-reviewed publications related to the Red Sea and the Arabian Gulf in order to assess the level of health risk associated with fish consumption among the Saudi consumers. As a part of this investigation, 73 fish species and 1,027 edible fish part samples from 12 sampling sites were studied and analyzed. The results yielded by this study indicate that consumption of some species of fish, due to their higher bio-accumulated metal concentrations, could be a threat for human health. Furthermore, consumption of some fish species collected from specific areas is highly likely to induce adverse health effects in humans. More specifically, high hazard index $(\mathrm{HI}>10)$ was obtained for some fish species as Epinephelus Tauvina and Cuttle fish species caught in Djeddah and coastal area of
Bahrain sites, respectively. Consequently, very close monitoring of heavy metal levels in different regions of $\mathrm{KSA}$ is recommended in order to assess the risks to consumer health. Further investigation on methyl mercury ( $\mathrm{MeHg}$ ) concentrations in edible fish parts should be performed in order to estimate consistent exposure and assess adverse health effects.

\section{Ethics}

Author declares no conflict of interest.

\section{References}

Abadi, D.R.V., S. Dobaradaran, I. Nabipour, X. Lamani and M. Ravanipour et al., 2015. Comparative investigation of heavy metal, trace and macro element contents in commercially valuable fish species harvested off from the Persian Gulf. Environ. Sci. Pollut. Res. Int., 22: 6670-6678. DOI: $10.1007 / \mathrm{s} 11356-014-3852-1$

Al-Balwai, H.F.A., F. Al-Misned, A. Zubair, A.G. Khalid and M. Shahid, 2013. A study on the concentration of heavy metals in water and sediments of natural water reservoir in Wadi Hanefah, Saudi Arabia and Uptake of Metals by a Fish, Poecilia latipinna. Pak. J. Zool., 45: 589-593.

Al-Ghanim, K.A., M. Abdelatty, L. Abdelfattah and S. Mahboob, 2015. Differential uptake of heavy metals by gill, muscles and liver of four selected fish species from red sea. Pak. J. Zool., 47: 1031-1036.

Al-Kahtani, M.A., 2009. Accumulation of heavy metals in Tilapia Fish (Oreochromis niloticus) from AlKhadoud Spring, Al-hassa, Saudi Arabia. Am. J. Applied Sci., 6: 2024-2029.

DOI: 10.3844 /ajassp.2009.2024.2029

Al-Misned, F.A. and M.G. Mortuza, 2015. Heavy metals and trace elements levels and its risk assessment in two edible fishes from wadi Hanifah, Riyadh, Saudi Arabia. J. Anim. Plant Sci., 25: 1764-1770.

Al-Rubaie, M.H., S.R. Walker and S.S. Salek, 2014. Evaluation of the gulf cooperation council centralized procedure: The way forward. Ther. Innov. Regul. Sci., 48: 709-716. DOI: 10.1177/2168479014529572

Al-Saleh, I. and N. Shinwari, 2002. Preliminary report on the levels of elements in four fish species from the Arabian Gulf of Saudi Arabia. Chemosphere, 48: 749-755. DOI: 10.1016/S0045-6535(02)00126-1

Ashraf, W., 2005. Accumulation of heavy metals in kidney and heart tissues of Epinephelus microdon fish from the Arabian Gulf. Environ. Monit. Assess., 101: 311-316. DOI: 10.1007/s10661-005-0298-4

Burger, J., 2009. Risk to consumers from mercury in bluefish (Pomatomus saltatrix) from New Jersey: Size, season and geographical effects. Environ. Res., 109: 803-811. DOI: 10.1016/j.envres.2009.07.005 
Burger, J., M. Gochfeld, N. Alikunhi, H. Al-Jahdali and D. Al-Jebreen et al.,2015. Human health risk from metals in fish from Saudi Arabia: Consumption patterns for some species exceed allowable limits. Hum. Ecol. Risk Assess., 21: 799-827. DOI: $10.1080 / 10807039.2014 .934585$

Burger, J., M. Gochfeld, Z. Batang, N. Alikunhi and R. Al-Jahdali et al., 2014a. Fish consumption behavior and rates in native and non-native people in Saudi Arabia. Environ. Res., 133: 141-148. DOI: 10.1016/j.envres.2014.05.014

Burger, J., M. Gochfeld, Z. Batang N. Alikunhi and R. Al-Jahdali et al., 2014b. Interspecific and locational differences in metal levels in edible fish tissue from Saudi Arabia. Environ. Monit. Assess., 186: 6721-6746. DOI: $10.1007 / \mathrm{s} 10661-014-3885-4$

Calabrese, S., W. D'Alessandro, S. Bellomo, L. Brusca and R.S. Martin, et al., 2015. Characterization of the Etna volcanic emissions through an active biomonitoring technique (moss-bags): part 1--major and trace element composition. Chemosphere, 119: 1447-1455. PMID: 25262949

Das, S., R. Raj, N. Mangwani, H.R. Dash and J. Chakraborty, 2014. Microbial Biodegradation and Bioremediation.

Dhanakumar, S., G. Solaraj and R. Mohanraj, 2015. Heavy metal partitioning in sediments and bioaccumulation in commercial fish species of three major reservoirs of river Cauvery delta region, India. Ecotoxicol Env. Saf., 113: 145-151.

DOI: 10.1016/j.ecoenv.2014.11.032

Dreyer, H.C., O. Bakås, E. Alfnes, O. Strandhagen and M. Kollberg, 2007. Global supply chain control: A conceptual framework for the global control centre (GCC). IFIP Int. Fed. Inf. Process., 246: 161-170.

Dumitrescu, C., D.M. Cocaârţă and A. Badea, 2012. An integrated modeling approach for risk assessment of heavy metals in soils. UPB Sci. Bull. Series D, 74: 217-228.

Dural, M., G. Lugal, A.A. Özak and B. Derici, 2006. Bioaccumulation of some heavy metals in different tissues of Dicentrarchus Labrax L, 1758, Sparus Aurata L, 1758 And Mugil Cephalus L, 1758 from the ÇamlIk lagoon of the eastern cost of Mediterranean (Turkey). Environ. Monit. Assess., 118: 65-74. DOI: 10.1007/s10661-006-0987-7

FAO, 2016. FAO fisheries and aquaculture-fishery and aquaculture country profiles. The Kingdom of Saudi Arabia. FAO.

Fernandes, C., A. Fontaínhas-Fernandes, F. Peixoto and M.A. Salgado, 2007. Bioaccumulation of heavy metals in Liza saliens from the Esmoriz-Paramos coastal lagoon, Portugal. Ecotoxicol. Environ. Saf., 66: 426-431.

DOI: $10.1016 /$ j.ecoenv.2006.02.007
Gallagher, C.M., J.J. Chen and J.S. Kovach, 2010. Environmental cadmium and breast cancer risk. Aging, 2: 804-814. PMID: 21071816

Graeme, K.A. and J. Pollack, 1998. Heavy metal toxicity, part I: Arsenic and mercury. J. Emerg. Med., 16: 45-56. DOI: 10.1016/S0736-4679(97)00241-2

GSO-GCC, 2016. GSO-GCC standardization organization.

Hanna, R.G.M., 1989. Levels of heavy metals in some Red Sea fish before hot brine pools mining. Mar. Pollut. Bull., 20: 631-635. DOI: $10.1016 / 0025-326 X(89) 90403-7$

Hosseini, M., S.M.B. Nabavi, S.N. Nabavi and N.A. Pour, 2015. Heavy metals (Cd, $\mathrm{Co}, \mathrm{Cu}, \mathrm{Ni}, \mathrm{Pb}$, $\mathrm{Fe}$ and $\mathrm{Hg}$ ) content in four fish commonly consumed in Iran: Risk assessment for the consumers. Environ. Monit. Assess., 187: 237-237. DOI: $10.1007 / \mathrm{s} 10661-015-4464-\mathrm{z}$

Idris, A.M., T.O. Said, A.A. Omran and K.F. Fawy, 2015. Combining multivariate analysis and human risk indices for assessing heavy metal contents in muscle tissues of commercially fish from Southern Red Sea, Saudi Arabia. Environ. Sci. Pollut. Res., 22: 17012-17021. DOI: 10.1007/s11356-015-4921-9

Järup, L. and A. Åkesson, 2009. Current status of cadmium as an environmental health problem. Toxicol. Applied Pharmacol., 238: 201-208. DOI: $10.1016 /$ j.taap.2009.04.020

Järup, L., 2003. Hazards of heavy metal contamination. Br. Med. Bull., 68: 167-182. DOI: 10.1093/bmb/ldg032

Jayaprakash, M., R.S. Kumar, L. Giridharan, S.B. Sujitha and S.K. Sarkar et al., 2015. Bioaccumulation of metals in fish species from water and sediments in macrotidal Ennore creek, Chennai, SE coast of India: A metropolitan city effect. Ecotoxicol. Environ. Saf., 120: 243-255. DOI: 10.1016/j.ecoenv.2015.05.042

Kamal, K.T., K. Lotfi, K.D. Omar, R.E. Mohamed and K.M. Abueliz et al., 2015. Heavy metals concentrations in fish from Red Sea and Arabian Gulf: Health benefits and risk assessments due to their consumption. Asian J. Chem., 27: 4411-4416.

Lando, A.M. and S.C. Lo, 2014. Consumer understanding of the benefits and risks of fish consumption during pregnancy. Am. J. Lifestyle Med., 8: 88-92. DOI: 10.1177/1559827613514704

Larsson, S.C., N. Orsini and A. Wolk, 2015. Urinary cadmium concentration and risk of breast cancer: A systematic review and dose-response meta-analysis. Am. J. Epidemiol., 182: 375-380.

DOI: $10.1093 / \mathrm{aje} / \mathrm{kwv} 085$

Madany, I.M., A.A.A. Wahab and Z. Al-Alawi, 1996. Trace metals concentrations in marine organisms from the coastal areas of Bahrain, Arabian Gulf. Water Air Soil Pollut., 91: 233-248. DOI: $10.1007 / \mathrm{BF} 00666260$ 
Mahaffey, K.R., L. Trip and J. Weiss, 1999. Methylmercury: A new look at the risks. Public Health Rep., 114: 396-415. PMID: 10590759

Mahboob, S., H.F.A. Al-Balawi, F. Al-Misned, S. Al-Quraishy and Z. Ahmad, 2014. Tissue metal distribution and risk assessment for important fish species from Saudi Arabia. Bull. Environ. Contam. Toxicol., 92: 61-66. DOI: $10.1007 / \mathrm{s} 00128-013-1139-8$

Malik, N., A.K. Biswas, T.A. Qureshi, K. Borana and R. Virha, 2010. Bioaccumulation of heavy metals in fish tissues of a freshwater lake of Bhopal. Environ. Monit. Assess., 160: 267-276. DOI: $10.1007 / \mathrm{s} 10661-008-0693-8$

Minic, Z., V. Serre and G. Hervé, 2006. Adaptation of organisms to extreme conditions of deep-sea hydrothermal vents. Comptes Rendus Biol., 329: 527-540. DOI: 10.1016/j.crvi.2006.02.001

Paulino, M.G., T.P. Benze, H. Sadauskas-Henrique, M.M. Sakuragui and J.B. Fernandes et al., 2014. The impact of organochlorines and metals on wild fish living in a tropical hydroelectric reservoir: Bioaccumulation and histopathological biomarkers. Sci. Total Environ., 497-498: 293-306. DOI: 10.1016/j.scitotenv.2014.07.122

Pelfrêne, A., S. Détriché and F. Douay, 2014. Combining spatial distribution with oral bioaccessibility of metals in smelter-impacted soils: implications for human health risk assessment. Environ. Geochem. Health, 37: 49-62. DOI: $10.1007 / \mathrm{s} 10653-014-9629-0$

Pourang, N., A. Nikouyan and J.H. Dennis, 2005. Trace element concentrations in fish, surficial sediments and water from northern part of the Persian Gulf. Environ. Monit. Assess., 109: 293-316. DOI: $10.1007 / \mathrm{s} 10661-005-6287-9$

Rana, S.V.S., 2014. Perspectives in endocrine toxicity of heavy metals-a review. Biol. Trace Elem. Res., 160: 1-14. DOI: 10.1007/s12011-014-0023-7
Ravankhah, N., R. Mirzaei and S. Masoum, 2016. Human health risk assessment of heavy metals in surface soil. J. Mazandaran Univ. Med. Sci., 26: 109-120.

Saei-Dehkordi, S.S. and A.A. Fallah, 2011. Determination of copper, lead, cadmium and zinc content in commercially valuable fish species from the Persian Gulf using derivative potentiometric stripping analysis. Microchem. J., 98: 156-162. DOI: $10.1016 / \mathrm{j}$. microc.2011.01.001

Said, T.O., A.A. Omran, K.F. Fawy and A.M. Idris, 2014. Heavy metals in twelve edible marine fish species from Jizan Fisheries, Saudi Arabia: Monitoring and assessment. Fresenius Environ. Bull., 23: 801-810.

Seite, R., 1956. Histological peculiarities in relation to the formation of mercurial crystals, during certain fixations, in nerve tissue. Comptes Rendus Hebd. Séances Académie Sci., 243: 790-791. PMID: 13374949

Selvanathan, S., E.A. Selvanathan, S. Albalawi and M. Hossain, 2015. Meat and fish consumption patterns in Saudi Arabia. Applied Econom., 48: 446-460. DOI: 10.1080/00036846.2015.1083081

Stratakis, N., T. Roumeliotaki, E. Oken, H. Barros and M. Basterrechea et al., 2016. Fish intake in pregnancy and child growth: A pooled analysis of 15 European and us birth cohorts. JAMA Pediatr, 170: 381-390. DOI: $10.1001 /$ jamapediatrics.2015.4430

Tilley, S.K. and R.C. Fry, 2015. Systems Biology in Toxicology and Environmental Health.

USEPA, 2005. Supplemental guidance for assessing cancer susceptibility from early-life exposure to carcinogens. US Environmental Protection Agency.

WHO, 2016. WHO textbar Ten chemicals of major public health concern.

Xu, Z., J. Li, Y. Pan and X. Chai, 2016. Human health risk assessment of heavy metals in a replaced urban industrial area of Qingdao, China. Environ. Monit. Assess., 188: 229-229. DOI: $10.1007 / \mathrm{s} 10661-016-5224-4$ 